Otimização dos custos de energia elétrica na programação do armazenamento e distribuição de água em redes urbanas

Edilaine Martins Soler 



\title{
Otimização dos custos de energia elétrica na programação do armazenamento e distribuição de água em redes urbanas
}

\author{
Edilaine Martins Soler
}

Orientador: Prof Dr Marcos Nereu Arenales

Dissertação apresentada ao Instituto de Ciências Matemáticas e de Computação - ICMC-USP, como parte dos requisitos para obtenção do título de Mestre em Ciências de Computação e Matemática Computacional.

\author{
USP - São Carlos \\ janeiro/2008
}



"Aos meus pais... sem eles eu não teria chegado até aqui." 



\section{Agradecimentos}

À Deus, por guiar e iluminar os meus passos.

Ao meu orientador Marcos Nereu Arenales, pela orientação, amizade e pela confiança depositada no desenvolvimento deste trabalho.

À minha mãe, ao meu pai e à minha irmã, por serem presentes em minha vida e me apoiarem nas minhas decisões.

Ao Gustavo, o amor da minha vida, que sempre me apoiou e incentivou. Obrigada pelo seu respeito, compreensão, paciência, carinho e amor!

À minha sobrinha Liz, por alegrar a minha vida.

Às minhas grandes amigas de Igaraçu, Aline e Lili, por me acompanharem desde a infância e juntas compartilharmos alegrias e tristezas.

À minha "família de São Carlos": Lê, Ana e Melina, adoro vocês!

Aos funcionários do SAAE - São Carlos, em especial ao Amilson, chefe do setor de geoprocessamento, pelas informações.

Aos amigos do Laboratório de Otimização pelos agradáveis cafezinhos.

Às professoras Franklina e Maristela, pela amizade e a atenção dedicadas a este trabalho.

Aos professores e funcionários do ICMC-USP que, direta ou indiretamente, contribuíram com este trabalho.

À FAPESP pela credibilidade e apoio financeiro. 



\section{Resumo}

O problema abordado nesta pesquisa consiste na distribuição de água em redes urbanas para o atendimento de demandas conhecidas, com o objetivo de minimizar o custo da energia elétrica necessária para o funcionamento de bombas hidráulicas. As bombas hidráulicas são utilizadas para captar água de poços artesianos ou estações de tratamento de água para abastecer reservatórios distribuídos por bairros de uma cidade, de onde a população será atendida por força gravitacional. Como o custo da energia elétrica varia ao longo do dia, se faz necessário um planejamento do funcionamento das bombas para que não sejam ligadas nos horários em que a energia elétrica é mais cara.

O problema de planejamento de estoque de água em reservatórios (PPEAR) consiste em decidir em quais períodos ou frações dos períodos do horizonte de planejamento as bombas hidráulicas que abastecem os reservatórios devem permanecer ligadas e em quais períodos ou frações dos períodos deve haver transporte de água entre os reservatórios para que a demanda de cada reservatório seja atendida em cada período e sejam respeitados os níveis mínimos e máximos de água nos reservatórios.

Uma solução heurística para resolver o PPEAR é proposta e analisada por comparação com as soluções obtidas pelo método de enumeração implícita. Resultados computacionais comprovam a eficiência da abordagem, tanto pela qualidade das soluções como pelo baixo tempo de resposta.

Palavras chave: otimização linear inteira, planejamento de reservatórios em sistemas de abastecimento urbano. 



\section{Abstract}

The problem focused in this study consists of reducing the eletrical energy cost necessary to the operation of hydraulic pumps. The hydraulic pumps are used to catch water from artesians wells or Water Treatment Station to supply tanks which are located in districts in a city, from which the population will be supplied by gravitational force. As the cost of electrical energy varies along the day, a schedule of the pumps run is necessary to avoid that they are not turned in the periods when the energy cost is more expensive.

The problem of water stock schedule in tanks (WSST) consists of deciding in which periods or parts of them of the horizon planning the hydraulic pumps have to put on, and in which periods or parts of them should transfer water among the tanks so that the demand of each tank is met for each period and lower and upper limits of water shouldn't be violated.

A heuristic solution is proposed and analyzed by comparing its solutions with the solutions obtained by the branch and bound method. Computational experiments show the efficiency of the heuristic.

Keywords: integer linear optimization, water caption scheduling in urban systems. 



\section{Sumário}

1 Introdução 1

2 Revisão Bibliográfica $\quad 4$

2.1 Otimização de sistemas de abastecimento de água . . . . . . . . . . 4

2.2 Problema de dimensionamento de lotes com múltiplas plantas . . . 8

3 O problema de captação e distribuição de água em redes urbanas 11

3.1 Sistemas de Abastecimento de Água . . . . . . . . . . . . . . . . . . . . 11

3.2 Definição do problema . . . . . . . . . . . . . . . . . . . . . . 13

3.2.1 Tarifas de Energia Elétrica . . . . . . . . . . . . . . 13

3.2.2 O Problema de Planejamento de Estoque de Água em

Reservatórios . . . . . . . . . . . . . 15

3.3 Modelagem matemática . . . . . . . . . . . . . . . . . . 17

4 Métodos de Solução 21

4.1 O método de enumeração implícita . . . . . . . . . . . . . . . . . . . . . . 22

4.2 Heurística . . . . . . . . . . . . . . . . . . . 24

4.2.1 Períodos Críticos, Pré-Críticos e Não Críticos . . . . . . . . 25

4.2.2 Estratégia de operação bombeamento/reservação para períodos não críticos . . . . . . . . . . . . . . . . . 28

4.2.3 Estratégia de operação bombeamento/reservação para períodos pré-críticos . . . . . . . . . . . . . 32

4.2.4 Estratégia de operação bombeamento/reservação para períodos críticos . . . . . . . . . . . . . . 32

5 Experimentos Computacionais $\quad 42$

5.1 Gerador de exemplares . . . . . . . . . . . . . . . . . . . . 42

$5.1 .1 \quad 1^{\text {a }}$ Classe de Exemplares . . . . . . . . . . . . . . . . . . . 42

$5.1 .22^{\text {a }}$ Classe de Exemplares . . . . . . . . . . . . . . . . . . 43

$5.1 .3 \quad 3^{\text {a }}$ Classe de Exemplares . . . . . . . . . . . . . . . . . . . . 44

$5.1 .44^{\text {a }}$ Classe de Exemplares . . . . . . . . . . . . . . . . 45 
5.1.5 $\quad 5^{\mathrm{a}}$ Classe de Exemplares . . . . . . . . . . . . . . . . 46

$5.1 .6 \quad 6^{\text {a }}$ Classe de Exemplares . . . . . . . . . . . . . . . . . . 47

5.2 Solução CPLEX $\chi$ Solução Heurística . . . . . . . . . . . . . . . . . 49

$5.2 .11^{\text {a }}$ Etapa de Testes . . . . . . . . . . . . . . . 49

$5.2 .2 \quad 2^{\text {a }}$ Etapa de Testes . . . . . . . . . . . . . . . . . . 51

$5.2 .3 \quad 3^{\mathrm{a}}$ Etapa de Testes . . . . . . . . . . . . . . . . 54

$5.2 .4 \quad 4^{\mathrm{a}}$ Etapa de Testes . . . . . . . . . . . . . . . 56

$5.2 .5 \quad 5^{\mathrm{a}}$ Etapa de Testes . . . . . . . . . . . . . . . . 58

$5.2 .6 \quad 6^{\mathrm{a}}$ Etapa de Testes . . . . . . . . . . . . . . 58

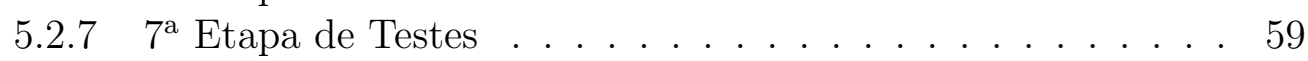

$5.2 .8 \quad 8^{\text {a }}$ Etapa de Testes . . . . . . . . . . . . . . . . . . . 59

$5.2 .9 \quad 9^{\mathrm{a}}$ Etapa de Testes . . . . . . . . . . . . . . . . . 60

$5.2 .1010^{\mathrm{a}}$ Etapa de Testes . . . . . . . . . . . . . . . . . . 60

$5.2 .1111^{\mathrm{a}}$ Etapa de Testes . . . . . . . . . . . . . . . . 61

$5.2 .1212^{\mathrm{a}}$ Etapa de Testes . . . . . . . . . . . . . . . . . 61

$5.2 .1313^{\mathrm{a}}$ Etapa de Testes . . . . . . . . . . . . . 61

6 Conclusões e Perspectivas $\quad 63$

$\begin{array}{ll}\text { A Algoritmo de Floyd } & 65\end{array}$

$\begin{array}{lc}\text { Referências Bibliográficas } & 66\end{array}$ 


\section{Lista de Figuras}

3.1 Sistema simples de abastecimento de água. Fonte: Tsutiya (2006). . 12

3.2 Sistema de abastecimento de água que atende a zona baixa e a zona alta. Fonte: Tsutiya (2006). . . . . . . . . . . . . . 12

3.3 Sistema de abastecimento de água com captação superficial e subterrâneo. Fonte: Tsutiya (2006). . . . . . . . . . . . . . . . 13

3.4 Parte do sistema de abastecimento de água apresentado na Figura 3.3. Fonte: Tsutiya (2006) . . . . . . . . . . . . . . . . . 13

3.5 Modalidades tarifárias disponíveis para cada tipo de consumidor. . . 15

3.6 Esquema simplificado de uma rede de abastecimento. Fonte: Toledo et al. (2006). . . . . . . . . . . . . . . . . 16

3.7 Balanço de água em dois períodos consecutivos. Fonte: Toledo et al. (2006). . . . . . . . . . . . . . . . 16

4.1 Árvore de enumeração. . . . . . . . . . . . . . . . . . . . . . . . 23

4.2 Horizonte de Planejamento de $24 \mathrm{~h}$ divido em períodos de uma hora, os períodos críticos estão em vermelho. . . . . . . . . . . . . . 26

4.3 Perdas de água do período 15 ao período $19 \ldots$. . . . . . . . . 26

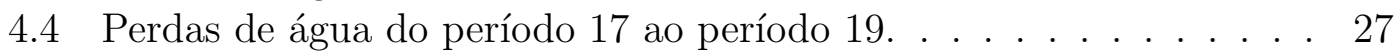

4.5 Sistema de abastecimento com 4 reservatórios. . . . . . . . . . . . . 33

4.6 Quantidade de água que o reservatório 1 pode enviar no período 20. 36

5.1 Sistema de abastecimento constituído por 3 reservatórios - $1^{\mathrm{a}}$ classe de exemplares. . . . . . . . . . . . . . . . . . 44

5.2 Sistema de abastecimento constituído por 30 reservatórios - $3^{\mathrm{a}}$ classe de exemplares. . . . . . . . . . . . . . . . . . 45

5.3 Sistema de abastecimento constituído por 4 reservatórios - $4^{\mathrm{a}}$ classe de exemplares. . . . . . . . . . . . . . . . 46

5.4 Sistema de abastecimento constituído por 8 reservatórios - $5^{\mathrm{a}}$ classe de exemplares. . . . . . . . . . . . . . . . 47

5.5 Sistema de abastecimento constituído por 9 reservatórios $-6^{\mathrm{a}}$ classe de exemplares. . . . . . . . . . . . . . . . . . . . . . 48 
5.6 Gráfico do Reservatório 1 para a solução obtida pelo CPLEX - sem perdas de água. . . . . . . . . . . . . . . . . . . 50

5.7 Gráfico do Reservatório 1 para a solução obtida pela heurística sem perdas de água. . . . . . . . . . . . . . . . . . 50

5.8 Gráfico do Reservatório 2 para a solução obtida pelo CPLEX - sem perdas de água. . . . . . . . . . . . . . . . . . . 51

5.9 Gráfico do Reservatório 2 para a solução obtida pela heurística sem perdas de água. . . . . . . . . . . . . . . . . 51

5.10 Gráfico do Reservatório 3 para a solução obtida pelo CPLEX - sem perdas de água. . . . . . . . . . . . . . . . . . . 52

5.11 Gráfico do Reservatório 3 para a solução obtida pela heurística sem perdas de água. . . . . . . . . . . . . . . . . 52

5.12 Gráfico do Reservatório 1 para a solução obtida pelo CPLEX perdas de água de 10\% . . . . . . . . . . . . . . . 53

5.13 Gráfico do Reservatório 1 para a solução obtida pela heurística perdas de água de 10\% . . . . . . . . . . . . . . . 54

5.14 Gráfico do Reservatório 2 para a solução obtida pelo CPLEX -

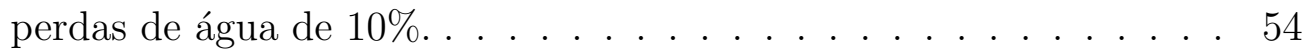

5.15 Gráfico do Reservatório 2 para a solução obtida pela heurística perdas de água de 10\% . . . . . . . . . . . . . . . . 55

5.16 Gráfico do Reservatório 3 para a solução obtida pelo CPLEX perdas de água de 10\% . . . . . . . . . . . . . . . . 55

5.17 Gráfico do Reservatório 3 para a solução obtida pela heurística perdas de água de $10 \% \ldots \ldots \ldots \ldots$. . . . . . . . . . 56

5.18 Gráfico do Reservatório 1 para a solução obtida pelo CPLEX perdas de água de $20 \% \ldots \ldots$. . . . . . . . . . . . . 57

5.19 Gráfico do Reservatório 1 para a solução obtida pela heurística perdas de água de $20 \% \ldots \ldots \ldots \ldots$. . . . . . . . . . . 57 


\section{Lista de Tabelas}

4.1 Demandas. . . . . . . . . . . . . . . . . . . . . . 34

5.1 Volumes mínimos e máximos dos reservatórios - $1^{\text {a }}$ classe de exemplares. . . . . . . . . . . . . . . . . 43

5.2 Volumes mínimos e máximos dos reservatórios - $4^{\mathrm{a}}$ classe de exemplares. . . . . . . . . . . . . . . . . 45

5.3 Vazão das bombas de captação - $4^{\mathrm{a}}$ classe de exemplares. . . . . . . 45

5.4 Volumes mínimos e máximos dos reservatórios - $5^{\mathrm{a}}$ classe de exemplares. . . . . . . . . . . . . . . . . . 46

5.5 Vazão das bombas de captação - $5^{\mathrm{a}}$ classe de exemplares. . . . . . . 47

5.6 Volumes mínimos e máximos dos reservatórios - $6^{\mathrm{a}}$ classe de exemplares. . . . . . . . . . . . . . . . . . . 48

5.7 Vazão das bombas de captação - $6^{\mathrm{a}}$ classe de exemplares. . . . . . . 48

5.8 Gaps obtidos pelo CPLEX e pela heurística - $1^{\mathrm{a}}$ etapa de testes. . . 49

5.9 Gaps obtidos pelo CPLEX e pela heurística - $2^{\mathrm{a}}$ etapa de testes. . . 53

5.10 Gaps obtidos pelo CPLEX e pela heurística - $3^{\text {a }}$ etapa de testes. . . 56

5.11 Gaps obtidos pelo CPLEX e pela heurística - $4^{\mathrm{a}}$ etapa de testes. . . 58

5.12 Gaps obtidos pelo CPLEX e pela heurística - $5^{\mathrm{a}}$ etapa de testes. . . 58

5.13 Gaps obtidos pelo CPLEX e pela heurística - $6^{\text {a }}$ etapa de testes. . . 59

5.14 Gaps obtidos pelo CPLEX e pela heurística - $7^{\mathrm{a}}$ etapa de testes. . . 59

5.15 Gaps obtidos pelo CPLEX e pela heurística - $8^{\mathrm{a}}$ etapa de testes. . . 60

5.16 Gaps obtidos pelo CPLEX e pela heurística - 9 $9^{\mathrm{a}}$ etapa de testes. . . 60

5.17 Gaps obtidos pelo CPLEX e pela heurística - 10 $0^{\mathrm{a}}$ etapa de testes. . 61 



\section{Capítulo 1}

\section{Introdução}

A água é um recurso natural indispensável à saúde e ao bem-estar da população. Os sistemas de abastecimento de água têm a função de levar água em quantidade e qualidade adequadas à população para que atenda as suas necessidades.

Nas décadas de 70 e 80, buscando atender a demanda decorrente do crescimento populacional urbano e da industrialização, as obras de saneamento, especialmente de sistemas de abastecimento de água às populações urbanas foram intensificadas.

O Brasil apresenta atualmente elevados índices de abastecimento urbano de água potável. Segundo a Pesquisa Nacional de Saneamento Básico realizada em 2000, pelo IBGE (Instituto Brasileiro de Geografia e Estatística), 97,9\% dos municípios do país contam com serviço de abastecimento de água prestado por alguma empresa pública ou privada (www.ibge.gov.br).

Segundo Tsutiya (2006) as despesas com energia elétrica nas empresas de saneamento básico entre 1993 e 1996 variaram entre 4,8\% e 36,3\% nos diversos estados brasileiros, e são o segundo ou terceiro item mais importante no orçamento das despesas de exploração. Assim, é muito relevante que as empresas de saneamento possam diminuir seus gastos com energia elétrica, sem prejuízo no abastecimento.

Este trabalho tem como objetivo minimizar o custo da energia elétrica necessária para o funcionamento de bombas hidráulicas. Na maioria dos sistemas de abastecimento de água há necessidade de utilizar Estações Elevatórias para recalcar água em reservatórios de distribuição e, para isso, bombas hidráulicas são utilizadas para captar água de poços (ou estações de tratamento) e abastecer reservatórios distribuídos por bairros de uma cidade, de onde a população é atendida. As bombas hidráulicas são acionadas quando o nível mínimo do reservatório é atingido e mantidas ligadas até que o nível máximo do reservatório seja atingido. Uma vez que as tarifas de energia elétrica variam ao longo das 
horas do dia, faz-se necessário um planejamento do funcionamento das bombas e, conseqüentemente, dos níveis dos reservatórios, a fim de evitar o funcionamento destas nos horários de alto custo de energia elétrica, respeitando-se restrições de demanda.

Em Toledo et al. (2006) é proposto um modelo de otimização linear inteira para este problema. A integralidade do modelo dificulta a sua resolução até a otimalidade por softwares comerciais e, por esta razão, apresentamos uma heurística que encontra uma solução em tempo computacional baixo e de boa qualidade.

O presente trabalho foi motivado num estudo sobre o sistema de abastecimento de água de um bairro isolado da cidade de São Carlos, (Seleghim (2004b)). O autor propôs uma política de acionamento das bombas hidráulicas que reduziu consideravelmente o custo com energia elétrica. Tal solução, entretanto, é limitada a um número pequeno de reservatórios e não analisa a interdependência dos reservatórios. Isto revela a importância deste trabalho, o qual pode proporcionar tanto uma economia significativa aos cofres públicos, como também um melhor uso do sistema elétrico nacional.

As soluções propostas no presente trabalho não requerem investimento em infra-estrutura ou qualquer alteração na estrutura de um sistema de abastecimento existente, são apenas mudanças nas políticas operacionais de bombeamento, de simples implantação na prática e que proporcionam economias significativas nos gastos com energia elétrica.

Para este trabalho foram analisados os métodos de solução existentes para problemas de otimização linear inteira e outros modelos propostos para otimização de sistemas de abastecimento de água, além do problema de dimensionamento de lotes com múltiplas plantas, pois este problema apresenta semelhanças com o modelo proposto em Toledo et al. (2006) para o problema de planejamento de estoque de água em reservatórios (PPEAR).

Apresentamos uma heurística baseada na intuição do problema para resolver o PPEAR, o princípio básico dessa heurística é evitar ligar as bombas hidráulicas de captação em horários em que a energia elétrica é mais cara, para isso algumas estratégias são usadas.

Inicialmente, no Capítulo 2, apresentamos uma revisão bibliográfica de trabalhos relacionados aos sistemas de abastecimento de água e de trabalhos relacionados ao problema de dimensionamento de lotes com múltiplas plantas. No Capítulo 3, apresentamos o problema em estudo, no qual descrevemos o funcionamento de um sistema de abastecimento de água e um modelo matemático para o problema de planejamento de estoque de água em reservatórios (PPEAR). No Capítulo 4 apresentamos os métodos de solução: método de enumeração implícita e a heurística proposta. No Capítulo 5 explicamos os experimentos 
computacionais realizados e apresentamos os resultados obtidos. Finalmente, no Capítulo 6, apresentamos as conclusões e as próximas etapas pretendidas. 


\section{Capítulo 2}

\section{Revisão Bibliográfica}

\subsection{Otimização de sistemas de abastecimento de água}

Almeida \& Barbosa (2002) propõem um modelo não-linear de otimização que tem como objetivo determinar políticas operacionais num período de $24 \mathrm{~h}$ que minimizem o consumo de energia elétrica associado às operações de bombeamento de água de uma estação tipo booster. O modelo proposto tem como restrições equações e inequações que representam relações necessárias para a operação do sistema de distribuição de água, como por exemplo: conservação da massa, conservação de energia, regime de operação das bombas, das válvulas e reservatórios, limitação das velocidades nas tubulações, limitação das pressões e dos níveis dos reservatórios. As variáveis de decisão do modelo são: vazões nos trechos; pressões nos nós; vazão, altura manométrica, rendimento hidráulico, condição operacional e rotação das bombas; níveis nos reservatórios e abertura geométrica das válvulas.

A solução para o modelo proposto foi obtida pelo software GAMS (General Algebric Modeling System) associando-se o solver CONOPT (Continuous Optimizer), que utiliza o algoritmo do Gradiente Reduzido Generalizado, com o solver SBB (Standard Branch-and-Bound) que utiliza o algoritmo de enumeração implícita.

Foram realizados testes computacionais considerando um sistema de distribuição de água composto por doze tubulações, dez nós, cinco demandas localizadas, uma estação tipo booster composta por uma bomba de rotação variável e dois reservatórios.

Os autores analisaram a influência dos níveis iniciais dos reservatórios no consumo de energia elétrica em três casos:

Caso 1: 
Foi admitido como nível inicial para os reservatórios 1 e 2 a combinação dos valores $0,20,40,60,80$ e $100 \%$ da capacidade total destes. O problema foi resolvido com cada uma das diversas combinações dos níveis iniciais dos reservatórios e as soluções comparadas. Entre as soluções encontradas, o mínimo com relação ao consumo diário de energia elétrica para a bomba do booster $(401,3 \mathrm{~kW})$ foi alcançado com os reservatórios 1 e 2 nos níveis iniciais de 60 e $80 \%$ de suas capacidades totais.

\section{Caso 2:}

O problema foi resolvido considerando os níveis iniciais dos reservatórios 1 e 2 como variáveis de decisão. Os autores concluíram que as condições iniciais ótimas para os níveis iniciais dos reservatórios 1 e 2 são respectivamente $49 \%$ e $76,6 \%$ de suas capacidades máximas e, neste caso, o consumo diário de energia pela bomba foi de $397.05 k W$.

\section{Caso 3:}

Almeida (2001) resolveu o problema tomando como níveis iniciais de ambos os reservatórios sendo $50 \%$ de suas capacidades totais. A solução ótima encontrada requer um consumo diário de energia elétrica para a bomba de $620,8 \mathrm{~kW}$.

Com os resultados obtidos para esses três casos, fica evidente a importância e necessidade de uma avaliação das condições iniciais do sistema de distribuição de água.

Para o caso apresentado, os autores concluíram que alterações dos níveis iniciais dos reservatórios podem representar economias de cerca de $36 \%$ no consumo de energia elétrica da bomba do booster.

Tsutiya (2006) propõe quatro alternativas operacionais de bombeamentoreservação buscando reduzir o custo de energia elétrica em sistemas de abastecimento de água:

Alternativa Operacional 1: manter as bombas hidráulicas ligadas constantemente com taxa de bombeamento igual à taxa de consumo médio diário.

Alternativa Operacional 2: o bombeamento deverá ser evitado nos horários de ponta (horários em que o custo da energia elétrica é mais elevado), para isso deverá haver um aumento de $14 \%$ na taxa de bombeamento nos demais horários do dia.

Alternativa Operacional 3: o bombeamento fora do horário de ponta deverá ser a uma taxa de $7 \%$ acima do consumo médio diário e durante o horário de ponta há duas possibilidades: taxa de bombeamento igual a $50 \%$ do consumo médio diário ou taxa de bombeamento de $100 \%$ do consumo médio durante apenas parte do período de ponta.

Alternativa Operacional 4: não deve haver bombeamento durante o horário de ponta e nem aumento da taxa de bombeamento nos demais horários. É possível 
adotar este método somente se a capacidade máxima do reservatório for maior do que a demanda total durante o horário de ponta somada a reservação (estoque) mínima permitida, pois dessa maneira a bomba poderá manter-se desligada durante todo o horário de ponta.

Para a aplicação do método operacional adequado deve haver um conhecimento prévio do volume útil dos reservatórios, das características hidráulicas das bombas e da forma de operação destas. Segundo o autor, a implantação das medidas operacionais adequadas, para cada um dos sistemas de abastecimento testados, resultaram em economias significativas com os custos de energia elétrica.

Carrijo et al. (2003) desenvolveram um modelo de otimização multiobjetivo direcionado ao controle operacional ótimo de sistemas de macro distribuição de água potável. O modelo tem como objetivos principais a minimização dos custos com energia elétrica nas estações de bombeamento e a maximização da confiabilidade hidráulica, considerando o índice de atendimento da demanda, os níveis adequados de água nos reservatórios e as pressões mínimas e máximas nos pontos de demanda, para um período de 24 horas. Os autores usaram o simulador hidráulico EPANET 2 e os algoritmos genéticos multiobjetivo como ferramentas para a otimização das operações do sistema.

Para a análise e avaliação dos resultados foi utilizada uma parte do sistema de macro adução da cidade de Goiânia no estado de Goiás. O objetivo principal do trabalho foi desenvolver uma ferramenta útil e bastante flexível para utilização por parte dos operadores de sistemas de abastecimento de água. Os autores concluíram que este objetivo ainda não foi plenamente alcançado, mas os resultados obtidos foram animadores.

Toledo et al. (2006) apresentam um modelo para o problema de minimizar o custo da energia elétrica necessária para a operação de bombas hidráulicas que captam água de poços artesianos ou Estações de Tratamento de Água e abastecem reservatórios distribuídos em bairros de uma cidade. O problema consiste em planejar o funcionamento das bombas hidráulicas para que estas não operem no horário de ponta, pois neste horário a energia elétrica é mais cara. Os autores consideram que as restrições hidráulicas estão satisfeitas e consideram apenas restrições de balanço de água.

Os autores apresentam um modelo de otimização linear inteiro misto, em que é considerado o custo de operação e acionamento das bombas hidráulicas. Desconsiderando o custo de acionamento das bombas, um segundo modelo de otimização linear é proposto. Um terceiro modelo de otimização é ainda apresentado, em que são consideradas perdas de água no sistema por vazamentos 
na rede de distribuição.

Foram realizados testes usando o pacote de otimização CPLEX 7.5. Os experimentos foram realizados em três etapas. Primeiramente foi avaliada a influência do tamanho do horizonte de planejamento na resolução dos problemas (foram analisados três horizontes de planejamento: 2, 7 e 180 dias), e se observou que as decisões de bombeamento de água seguem uma comportamento padrão: nos períodos que antecedem os horários de ponta (alto custo de energia elétrica) é armazenado um volume de água suficiente para suprir as demandas durante o horário de ponta. Na segunda etapa foi analisada a política de acionamento das bombas para o modelo inteiro misto e para o modelo linear, em que se observou que nas soluções encontradas para o modelo inteiro misto as bombas são ligadas um número menor de vezes, o que facilita a operação do sistema. Na terceira etapa foi avaliado o impacto de vazamentos existentes na rede na política de planejamento, em que se observou que quanto maior a perda de água a política ótima tende a manter os reservatórios com os volumes mínimos permitidos, não enchendo totalmente os reservatórios, mesmo nos períodos que antecedem os horários de ponta, nesta etapa os autores perceberam que as perdas de água aumentam de maneira significativa o custo total de operação do sistema e o modelo permite avaliar o custo/benefício de investimentos na melhoria das redes de distribuição de água.

Seleghim (2004a) analisa as condições de funcionamento da estação de captação e armazenamento de água do bairro Santa Felícia (São Carlos - SP) com relação à captação, à reservação e ao abastecimento de água e apresenta estratégias de operação visando reduzir custos operacionais e a preservação de equipamentos.

A estação engloba um poço e 3 reservatórios denominados elevado (capacidade de $200 \mathrm{~m}^{3}$ ), apoiado (capacidade de $400 \mathrm{~m}^{3}$ ) e metálico (capacidade de $2000 \mathrm{~m}^{3}$ ). A operação do sistema é feita por funcionários do SAAE, cujo trabalho consiste em acionar ou interromper o funcionamento das bombas e manipular as válvulas em função dos níveis dos reservatórios, do horário e de comandos externos eventuais.

Foi feito um monitoramento do horário de funcionamento da bomba, dos níveis dos reservatórios e da vazão de água extraída do poço durante os meses de abril, maio e junho de 2004, englobando igualmente períodos de calor e de frio intenso. O autor observou que a bomba do poço permanece ociosa por cerca de $50 \%$ do tempo, concentrado no período da madrugada; o acionamento desta em horários de ponta ocorre em cerca de $10 \%$ de seu tempo de funcionamento e o nível do reservatório elevado permanece aproximadamente $2 \mathrm{~h}$ por dia abaixo ou próximo de seu nível mínimo.

Foram propostas três etapas de otimização visando sanar os problemas encontrados, além de reduzir custos e melhorar o abastecimento. A primeira 
etapa consiste em realizar modificações físicas na instalação. A segunda etapa consiste na automatização parcial do sistema (acionamento das bombas e lógica de controle), em que se pode obter uma redução de aproximadamente $10 \%$ no custo da energia elétrica consumida, além de proporcionar melhoria substancial na qualidade do abastecimento pela redução de falhas operacionais. A terceira etapa consiste na automatização completa do sistema, incluindo a transmissão de sinais para a central de controle do SAAE, nesta condição o investimento é significativamente maior e os benefícios são a redução de $10 \%$ no custo da energia elétrica e a possibilidade de funcionamento sem a presença de operadores locais.

Seleghim (2004b) descreve a lógica de operação original do reservatório de Douradinho (São Carlos), que é baseada em duas ações: acionamento da bomba hidráulica quando o nível mínimo do reservatório é detectado e desligamento da bomba quando o nível máximo é atingido, sem a preocupação de evitar o funcionamento da bomba durante os horários de ponta.

A lógica de controle proposta pelo autor visa minimizar o acionamento das bombas em horários de ponta, para isso é necessário que o reservatório esteja o mais cheio possível no início do horário de ponta de forma que não seja necessário acionar a bomba nesse período. Isso pode ser feito acionando-se a bomba no período que antecede o horário de ponta mesmo que o nível do reservatório não tenha ainda alcançado seu nível mínimo.

Foram realizados testes com a lógica de controle proposta durante o período de $12 / 12 / 2003$ a 12/03/2004 em que observou-se que a bomba sempre teve seu funcionamento interrompido nos horários de ponta, sem prejuízo para o abastecimento da população do bairro.

A lógica de controle proposta não considera as possíveis ligações existentes entre reservatórios, o que possibilita a transferência de água entre estes.

\subsection{Problema de dimensionamento de lotes com múltiplas plantas}

O modelo matemático do PPEAR apresenta fortes semelhanças ao problema de dimensionamento de lotes com múltiplas plantas. Este problema consiste em planejar a produção em várias plantas e há a possibilidade de transferência de produção de uma planta para outra.

O PPEAR apresenta vários reservatórios (plantas) e há a possibilidade de transferência de água (produção) entre estes. No problema de dimensionamento de lotes com múltiplas plantas a função objetivo consiste em minimizar a soma dos custos de produção, de estoque e de transferência de produtos entre as plantas. 
No PPEAR a função objetivo consiste em minimizar o somatório dos custos de captação, de acionamento das bombas hidráulicas de captação e de transferência de água entre os reservatórios, não o custo de estoque, porém há perda de água estocada (perda de produto) representado nas restrições de balanço de estoque.

Quanto as restrições, ambos os problemas apresentam restrições de balanço de estoque. No problema de dimensionamento de lotes com múltiplas plantas há limitação da capacidade de produção em cada planta. No PPEAR esta capacidade é limitada pela vazão da bomba de captação que abastece o reservatório. No problema de dimensionamento de lotes com múltiplas plantas há restrições que garantem que se houver produção em um período há o custo de setup, enquanto no PPEAR as restrições garantem que só há o custo de acionamento da bomba de captação se esta não estiver ligada durante todo o período precedente. Ambos os modelos apresentam restrições de nã-negatividade e de integralidade. Além disso, o PPEAR apresenta restrições que limitam inferiormente e superiormente o estoque de água em cada período, para cada reservatório.

Sambasivan \& Schimidt (2002) propõem uma heurística para o problema de dimensionamento de lotes com múltiplas plantas, múltiplos ítens, múltiplos períodos, restrições de capacidade e com um único estágio de produção.

$\mathrm{Na}$ heurística proposta, os autores encontram inicialmente uma solução para o problema sem restrições de capacidade e testam as restrições de capacidade violadas, as quais são eliminadas por dois procedimentos: transferência de lotes de produção entre plantas num mesmo período ou transferência de lotes de produção em uma mesma planta em períodos diferentes. Foram testadas 256 exemplares para verificar a eficiência da heurística comparando a solução com uma relaxação linear usando o pacote LINDO. A solução obtida pela heurística teve um gap médio de $2,6 \%$.

Sambasivan \& Yahya (2005) propõem uma heurística baseada em Relaxação Lagrangiana para o mesmo problema. Na heurística proposta, as restrições de capacidade são relaxadas. O método consiste em resolver inicialmente o problema relaxado tomando os multiplicadores de Lagrange iguais a zero. Enquanto houver restrições de capacidade violadas, estas violações são eliminadas por dois procedimentos: transferência de lotes de produção entre plantas num mesmo período ou transferência de lotes de produção em uma mesma planta em períodos diferentes e os multiplicadores de Lagrange são atualizados de acordo com o método do subgradiente. Este procedimento é executado até serem eliminadas as violações das restrições de capacidades.

Diversos testes foram realizados para avaliar a eficiência da heurística proposta e os autores concluíram que o aumento do número de plantas não ocasiona aumento 
significativo no gap, mas cresce o tempo de processamento; a quantidade de períodos não causa impacto no gap e nem no tempo de processamento; quanto ao número de ítens observaram que conforme o número de ítens cresce o gap decresce, sem causar influência significativa no tempo de processamento. Os autores concluíram que a heurística Lagrangiana obtem boas soluções para o problema de dimensionamento de lotes com múltiplas plantas, capacitado e com transferência entre plantas.

Para o mesmo problema Nascimento (2007) propõe uma heurística baseada na meta-heurística GRASP com path relinking. A heurística proposta consiste basicamente de três etapas: construção da solução inicial, busca local e estratégia path relinking. A heurística foi testada para o problema de dimensionamento de lotes capacitado em máquinas paralelas e para o problema de dimensionamento de lotes em múltiplas plantas. Os resultados obtidos para este útimo foram comparados com os resultados obtidos pela heurística Lagrangiana de Sambasivan \& Yahya (2005). Para verificar a eficiência do path relinking foram realizados testes sem este procedimento e com este procedimento.

A autora concluiu que o GRASP puro obteve soluções competitivas com as da literatura e o desempenho da heurística proposta foi significativamente melhor para uma certa classe de problemas e o tempo médio, significativamente inferior para todas as classes comparados ao da literatura. Ao se incorporar a estratégia path relinking ao GRASP, foram obtidas soluções de melhor qualidade apesar do aumento do tempo computacional. 


\section{Capítulo 3}

\section{O problema de captação e distribuição de água em redes urbanas}

Neste capítulo inicialmente apresentamos a composição de um sistema de abastecimento de água e a sua funcionalidade, em seguida apresentamos um modelo que tem como objetivo reduzir os gastos com energia elétrica em sistemas de abastecimento.

\subsection{Sistemas de Abastecimento de Água}

Segundo Tsutiya (2006) a concepção dos sistemas de abastecimento de água é extremamente dependente do porte da cidade, topografia, e sua posição em relação aos mananciais. De um modo geral os sistemas são constituídos dos seguintes elementos:

- Manancial: corpo de água superficial ou subterrâneo, de onde é retirada a água para o abastecimento populacional;

- Captação: conjunto de estruturas e dispositivos, construídos ou montados junto ao manancial, para a retirada de água destinada ao sistema de abastecimento;

- Estação Elevatória: conjunto de obras e equipamentos para recalcar a água para a unidade seguinte;

- Adutora: canalizações para conduzir água entre unidades que precedem a rede de distribuição; 
- Estação de Tratamento de Água (ETA): unidade onde a água é tratada para atender as normas e padrões de potabilidade vigentes no país;

- Reservatório: unidade do sistema onde a água tratada é armazenada para ser distribuída aos consumidores;

- Rede de Distribuição: tubulações e acessórios para levar água potável até os consumidores.

Nas Figuras 3.1, 3.2 e 3.3 são apresentadas algumas concepções de sistemas de abastecimento de água.

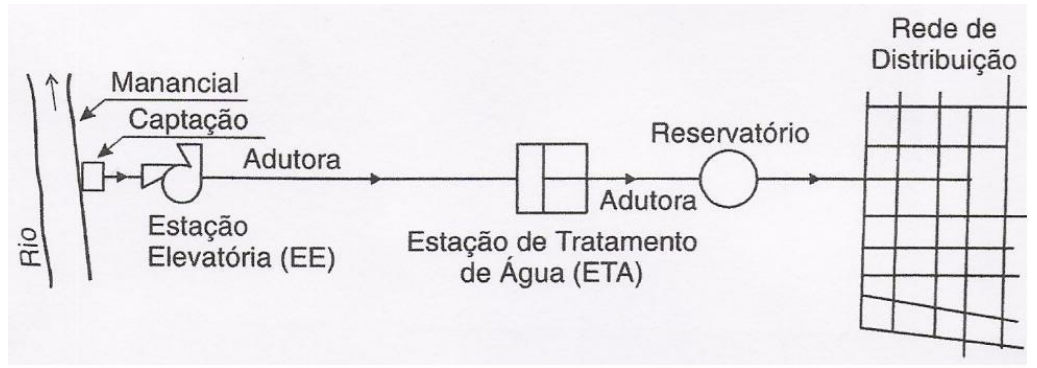

Figura 3.1: Sistema simples de abastecimento de água. Fonte: Tsutiya (2006).

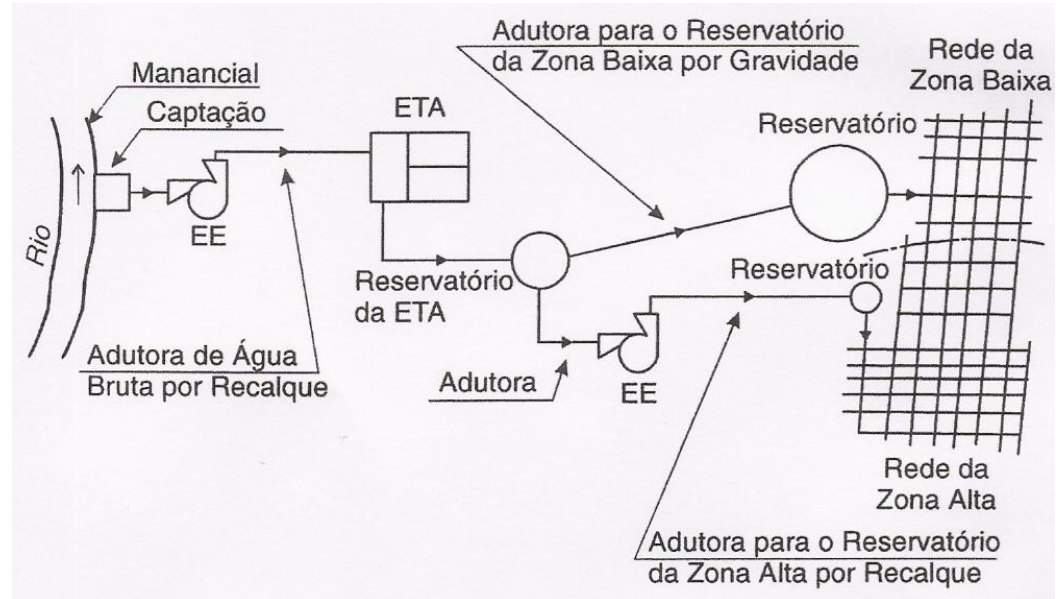

Figura 3.2: Sistema de abastecimento de água que atende a zona baixa e a zona alta. Fonte: Tsutiya (2006).

Basicamente, o funcionamento de um sistema de abastecimento de água consiste de captação da água do manancial, tratamento da água na Estação de 


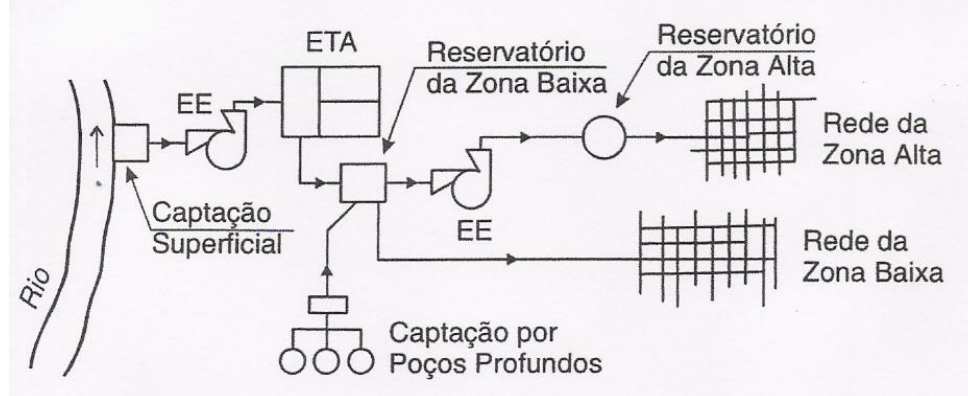

Figura 3.3: Sistema de abastecimento de água com captação superficial e subterrâneo. Fonte: Tsutiya (2006).

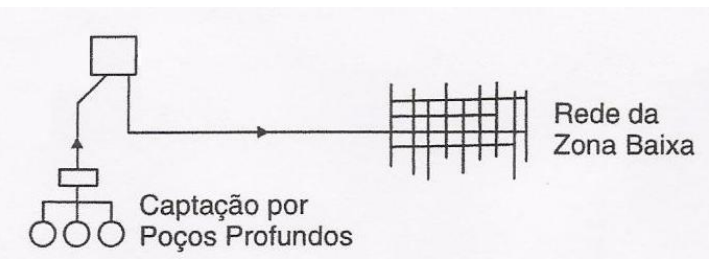

Figura 3.4: Parte do sistema de abastecimento de água apresentado na Figura 3.3. Fonte: Tsutiya (2006).

Tratamento de Água, reservação e distribuição ao consumidor. Há casos em que a água captada não necessita de tratamento, como podemos ver na Figura 3.4, a água é captada do poço, armazenada no reservatório e distribuída para a população.

\subsection{Definição do problema}

\subsubsection{Tarifas de Energia Elétrica}

As tarifas de energia elétrica são determinadas pela Agência Nacional de Energia Elétrica - ANEEL, que estabelece também os critérios de classificação dos consumidores e as formas de cobrança de energia elétrica. Uma unidade consumidora é classificada em função da atividade exercida e para efeito de faturamento, os consumidores são classificados em dois grupos: Grupo A (alta tensão) e Grupo B (baixa tensão).

As empresas de saneamento básico são classificadas como consumidores do Grupo A. Os consumidores deste grupo são faturados com componentes de demanda e de consumo. A cobrança de tarifas para este grupo pode ser feita 
segundo dois sistemas: o convencional e o horo-sazonal (azul ou verde).

Abaixo descrevemos cada uma destas modalidade tarifárias com base no Manual de Orientação ao Cliente (http : //www.cpfl.com.br) fonecido pela CPFL (Companhia Paulista de Força e Luz, empresa responsável pelo fornecimento de energia elétrica para o estado de São Paulo).

A estrutura tarifária convencional é caracterizada pela aplicação de uma tarifa para o consumo de energia elétrica ( $\mathrm{kWh}$ ) e uma tarifa para a demanda de potência $(\mathrm{kW})$ independentemente das horas de utilização do dia.

A estrutura tarifária azul é caracterizada pela aplicação de tarifas diferenciadas para o consumo de energia elétrica (KWh) de acordo com as horas de utilização do dia e os períodos do ano, bem como tarifas diferenciadas para a demanda de potência $(\mathrm{kW})$ de acordo com as horas de utilização do dia. Na estrutura tarifária azul a utilização de energia, ou seja, as tarifas da demanda de potência e de consumo de energia no horário de ponta são mais elevadas do que as do horário fora de ponta. As tarifas aplicadas no período seco são ligeiramente mais elevadas que as no período úmido.

O horário de ponta é um período de três horas contínuas a ser estabelecido pela concessionária de energia elétrica, compreendido diariamente entre 17:00 e 22:00 horas, de segunda-feira à sexta-feira. No estado de São Paulo este intervalo é das 18:00 às 21:00 no horário convencional e das 19:00 às 22:00 no horário de verão.

Pela Resolução no 445 da ANEEL, de 3 de abril de 2007, o preço da demanda, na tarifa horo-sazonal azul é da ordem de três vezes mais cara nos horários de ponta do que nos horários fora de ponta. No preço de consumo, a diferença dos preços é da ordem de duas vezes mais cara nos horários de ponta do que nos horários fora de ponta.

A estrutura tarifária verde é caracterizada pela aplicação de tarifas diferenciadas para o consumo de energia elétrica $(\mathrm{kWh})$ de acordo com as horas de utilização do dia e os períodos do ano, bem como uma única tarifa para demanda de potência $(\mathrm{kW})$. Na estrutura tarifária verde as tarifas de consumo de energia no horário de ponta são mais elevadas do que as do horário fora de ponta. Pela Resolução $\mathrm{n}^{\circ} 445$ da ANEEL, de 3 de abril de 2007, vemos que nas tarifas de consumo de energia, a diferença dos preços é da ordem de 4 a 5 vezes mais cara nos horários de ponta do que nos horários fora de ponta.

Segundo o Manual de orientação ao Cliente, de acordo com o valor para a demanda contratada e a tensão, os consumidores podem optar pela modalidade de cobrança de tarifas. Consumidores com demanda contratada inferior a 300 $\mathrm{kW}$ e em tensão de fornecimento inferior a $69 \mathrm{kV}$ podem escolher qualquer uma das modalidades: convencional, verde ou azul. Consumidores com demanda contratada igual ou superior a $300 \mathrm{~kW}$ e em tensão de fornecimento inferior a $69 \mathrm{kV}$ devem obrigatoriamente escolher entre as modalidades tarifárias azul ou 
verde. E as unidades consumidoras atendidas em tensão de fornecimento igual ou superior a $69 \mathrm{kV}$ adotam obrigatoriamente a modalidade tarifária azul.

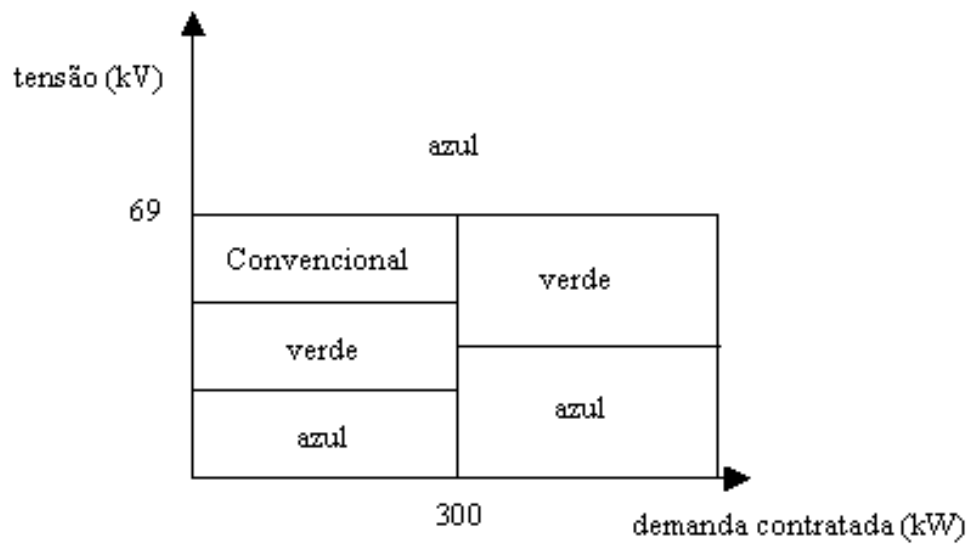

Figura 3.5: Modalidades tarifárias disponíveis para cada tipo de consumidor.

Como as tarifas de energia elétrica variam ao longo do dia para os consumidores que utilizam a tarifa horo-sazonal, torna-se necessário em um sistema de abastecimento de água um planejamento do horário de funcionamento das bombas hidráulicas e, conseqüentemente, dos níveis dos reservatórios em um horizonte de planejamento.

\subsubsection{O Problema de Planejamento de Estoque de Água em Reservatórios}

O problema de planejamento de estoque de água em reservatórios (PPEAR) consiste em decidir, em cada período do horizonte de planejamento, as operações (liga/desliga) das bombas hidráulicas que abastecem os reservatórios e a transferência de água entre os reservatórios de modo que a demanda de cada reservatório seja atendida em cada período e sejam respeitados os níveis mínimos e máximos de água nos reservatórios. Além disso, é considerado um custo de acionamento das bombas hidráulicas, de modo a minimizar o número de vezes que as bombas são acionadas, facilitando a implantação da solução na prática.

Na Figura 3.6 ilustramos o problema considerando três reservatórios. Nesta figura os círculos representam os poços ou estações de tratamento de água; os cilindros são os reservatórios; os triângulos são as bombas; os retângulos são os centros consumidores e os arcos são as adutoras: entre os poços/ETA e os reservatórios, entre os reservatórios e entre os reservatórios e os centros 
consumidores.

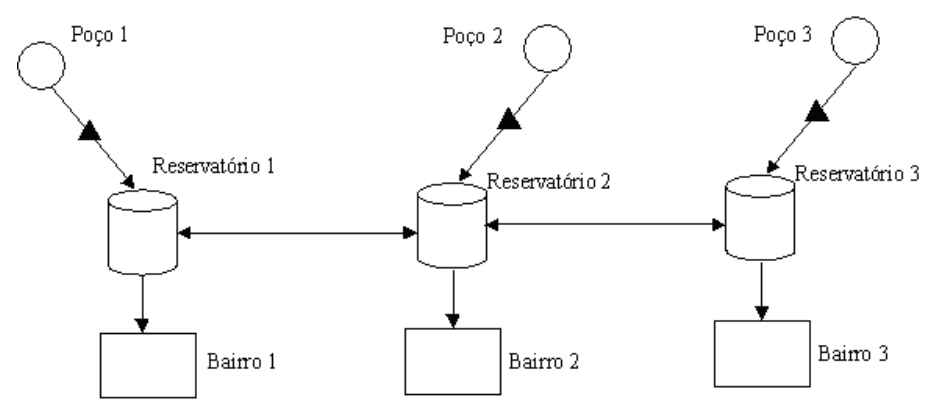

Figura 3.6: Esquema simplificado de uma rede de abastecimento. Fonte: Toledo et al. (2006).

Na Figura 3.7 ilustramos o que ocorre em cada reservatório em dois períodos consecutivos. Nesta Figura, os arcos que ligam um mesmo reservatório de um período ao próximo, digamos período $t$ ao período $t+1$ representam o estoque (reservação) de água no reservatório, ao final do período $t$.

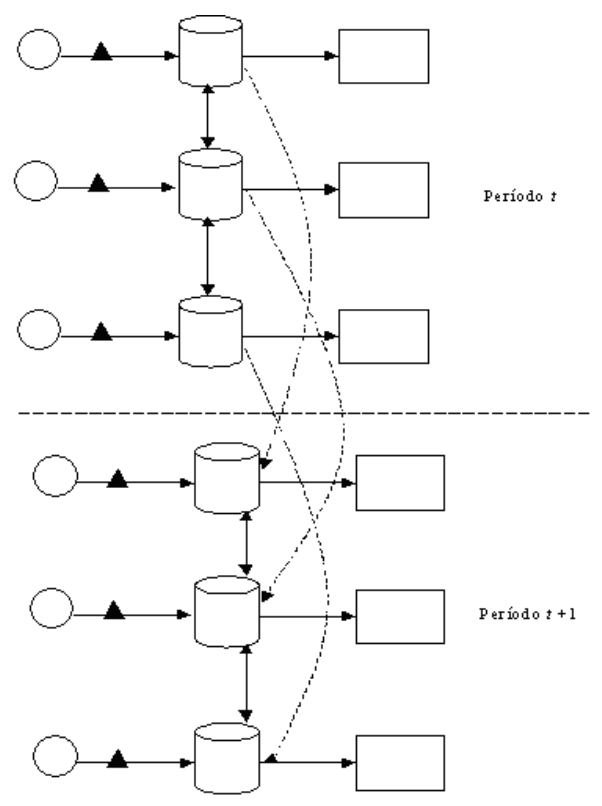

Figura 3.7: Balanço de água em dois períodos consecutivos. Fonte: Toledo et al. (2006).

Em sistemas reais de abastecimento de água é muito comum perda de água 
devido aos vazamentos na rede de distribuição, essas perdas são proporcionais à pressão na rede e, portanto, são proporcionais ao volume de água nos reservatórios. Assim, quanto maior o volume de água armazenada em um reservatório, maior é a quantidade de água perdida.

\subsection{Modelagem matemática}

Em Toledo et al. (2006) é proposto um modelo de otimização linear inteiro misto, o qual tem como objetivo minimizar o custo da energia elétrica necessária para o funcionamento das bombas hidráulicas que captam água dos poços artesianos ou de estações de tratamento de água e abastecem os reservatórios distribuídos por bairros de uma cidade, este modelo considera as perdas de água presentes em um sistema.

A seguir apresentamos o modelo matemático de programação inteira mista proposto em Toledo et al. (2006).

\section{Índices:}

$\mathrm{j}=1 \ldots \mathrm{R}$; reservatórios;

$\mathrm{k}=1 \ldots \mathrm{B}$; centros consumidores;

$\mathrm{t}=1 \ldots \mathrm{T} ;$ períodos (horizonte de planejamento);

\section{Dados:}

$d_{k t}=$ demanda $\left(m^{3}\right)$ do centro consumidor (bairro) $k$ durante o período $t$;

$c_{j t}=$ custo de manter ligada a bomba $j$ durante todo o período $t$;

$s_{j t}=$ custo de acionamento da bomba $j$ no período $t$;

$v_{j t}=\operatorname{vazão}\left(m^{3}\right)$ da bomba $j$ no período $t$ (varia de acordo com o tamanho do período);

$w_{j l t}=\operatorname{vazão}\left(m^{3}\right)$ da bomba para transportar água do reservatório $j$ para o reservatório $l$ no período $t$ (varia de acordo com o tamanho do período);

$h_{j}^{\text {min }}=$ volume $\left(m^{3}\right)$ mínimo do reservatório $j$ (restrição de segurança); 
$h_{j}^{\max }=$ volume $\left(m^{3}\right)$ máximo do reservatório $j$ (restrição física);

$h_{j}^{0}=$ volume $\left(m^{3}\right)$ do reservatório $j$ no início do horizonte de planejamento $(t=0)$;

$x_{j 0}^{0}=$ estado inicial da bomba $\mathrm{j}\left(x_{j 0}^{0}=0\right.$ se a bomba estiver desligada ou $x_{j 0}^{0}=1$ se a bomba estiver ligada);

$S_{j}=\{k$, tal que o centro consumidor $k$ é abastecido pelo reservatório $j\}$;

$R_{j}=\{l$, tal que o reservatório $l$ pode receber água do reservatório $j\} ;$

$P_{j}=\{l$, tal que o reservatório $l$ pode enviar água para o reservatório $j\}$;

$\gamma_{j l t}=$ custo de transferir água do reservatório $j$ para o reservatório $l$ durante todo o período $t$ (pode haver elevação e uma bomba deve ser acionada, caso contrário, se por gravidade, o custo é nulo).

$\theta_{j t}=$ fração da água no reservatório $j$ perdida por vazamento durante o período $t$;

\section{Variáveis de decisão:}

$I_{j t}=$ volume de água $\left(m^{3}\right)$ no reservatório $j$, estocada ao final do período $t$;

$x_{j t}=$ fração do período $t$ em que a bomba $j$ é mantida ligada (Obs: $x_{j t}$ vezes o tamanho do período em horas, fornece o tempo que a bomba permaneceu ligada, em horas. Além disso, $v_{j t} x_{j t}$ fornece o volume, em $m^{3}$ de água captada no período t pela bomba j);

$y_{j t}= \begin{cases}1, & \left.\text { se } x_{j t}>0 \text { (isto é, há captação de água no período } t\right) \\ 0, & \text { caso contrário }\end{cases}$

$\alpha_{j t}= \begin{cases}1, & \text { se a bomba } j \text { é acionada no período } t \\ 0, & \text { caso contrário; }\end{cases}$

OBS: Se uma bomba $j$ permanecer ligada durante todo o período $t-1$, isto é, $x_{j, t-1}=1$, então esta bomba não será acionada no período $t$ uma vez que já está ligada (não há o custo de acionar a bomba).

$z_{j l t}=$ fração do período $t$ na qual existe transporte de água do reservatório $j$ para 
o reservatório $l$ (Obs: $z_{j l t} w_{j l t}$ fornece o volume de água transferido do reservatório $j$ para o reservatório $l$, no período $t)$.

O modelo matemático:

$$
\text { Minimizar } \sum_{t=1}^{T} \sum_{j=1}^{R}\left(c_{j t} x_{j t}+s_{j t} \alpha_{j t}\right)+\sum_{t=1}^{T} \sum_{j=1}^{R} \sum_{l \in R_{j}} \gamma_{j l t} z_{j l t}
$$

Sujeito a

$$
\begin{aligned}
& I_{j t}=\left(1-\theta_{j, t}\right) I_{j, t-1}+v_{j t} x_{j t}+\sum_{l \in P_{j}} w_{l j t} z_{l j t}-\sum_{l \in R_{j}} w_{j l t} z_{j l t}-\sum_{k \in S_{j}} d_{k t} \quad j=1, \ldots, R, t=1, \ldots, T \\
& x_{j t} \leq y_{j t} \quad j=1, \ldots, R, t=1, \ldots, T \\
& \alpha_{j t} \geq y_{j t}-x_{j, t-1} \quad j=1, \ldots, R, t=1, \ldots, T \\
& h_{j}^{\min } \leq I_{j t} \leq h_{j}^{\max } \quad j=1, \ldots, R, t=1, \ldots, T \\
& 0 \leq z_{l j t} \leq 1 \quad l, j=1, \ldots, R, t=1, \ldots, T \\
& x_{i j} \geq 0 \quad j=1, \ldots, R, t=1, \ldots, T \text {; } \\
& x_{j 0}=x_{j 0}^{0}, I_{j 0}=h_{j}^{0} \quad j=1, \ldots, R ; \\
& y_{j t} \in\{0,1\}, \alpha_{j t} \in\{0,1\} \quad j=1, \ldots, R, t=1, \ldots, T \text {; }
\end{aligned}
$$

A função objetivo (3.1) representa o custo total de energia elétrica necessária para o funcionamento das bombas hidráulicas de um sistema de abastecimento de água. Este custo é dado pelo custo de acionar as bombas para captação mais o custo de mantê-las ligadas, somados aos custos de manter ligadas as bombas de transferência de água entre os reservatórios (os custos de ligar as bombas de transferência não são considerados, pois as bombas tendem a serem acionadas somente durante os horários de ponta não dificultando a implantação da solução na prática). As equações (3.2) representam o balanço de estoque de água em cada período e em cada reservatório, e são consideradas as perdas de água em cada período. As restrições (3.3) obrigam as variáveis $y_{j t}$ assumirem o valor 1 se $x_{i j}>0$. Nas restrições (3.4) garantimos que se a bomba estiver ligada durante todo o período $t-1$, para utilizá-la no período $t$ não haverá custo de acionamento. As restrições (3.5) garantem que os volumes de cada reservatório, em cada período, estejam entre os limites mínimo e máximo pré-estabelecidos. As restrições (3.6) asseguram que as bombas para transferência de água podem permacer desligadas durante todo o período $\left(z_{l j t}=0\right)$ ou ligadas em parte dos períodos $\left(0<z_{l j t}<1\right)$ ou ligadas durante todo o período $\left(z_{l j t}=1\right)$. As restrições (3.7) juntamente 
com as restrições (3.3) asseguram que as bombas de captação podem permanecer desligadas durante todo o período $\left(x_{j t}=0\right)$ ou ligadas em parte do período $(0<$ $x_{j t}<1$ ), pois para $x_{j t}>0$ a variável $y_{j t}$ assume o valor 1 ) ou ligadas durante todo o período $\left(x_{j t}=1\right)$. Em $(3.8)$, as bombas podem ser ajustadas para desligadas no início do horizonte de planejamento com $x_{j 0}^{0}=0$, ou ligadas com $x_{j 0}^{0}=1$ e o volume inicial de água nos reservatórios é declarado. Em (3.9), as variáveis $\alpha_{j t} \mathrm{e}$ $y_{j t}$ são definidas como binárias.

O modelo proposto não prevê explicitamente reações a eventos aleatórios como aumento não previsto de demanda provocado por eventos aleatórios (como calor intenso, por exemplo) ou perdas de água não previstas ocasionadas por problemas de infra-estrutura no sistema de abastecimento de água. Porém, são apresentadas três estratégias para estas situações. Na primeira, o volume mínimo de água préestabelecido nos reservatórios deve ser capaz de atender a demanda de imediato no caso de ocorrer aumento brusco da demanda. Ou seja, o estoque mínimo de água de segurança atenua a componente estocástica da demanda que poderia causar falta de água temporária à população. Na segunda estratégia, o planejamento proposto pelo modelo pode ser aplicado sob a ótica de horizonte rolante, ou seja, resolve-se o problema considerando um horizonte de T períodos e aplica-se apenas as decisões dos primeiros períodos, inclui-se novos períodos no final do horizonte, atualizase as demandas e os níveis de água nos reservatórios e o modelo é novamente resolvido. A ocorrência de algum evento aleatório importante é atenuada pelo novo planejamento. Finalmente, existe um procedimento padrão adotado nos sistemas de abastecimento de água que, na eventualidade de uma falha do modelo, ou no surgimento de evento extraordinário, é automaticamente acionado garantindo o suprimento de água. 


\section{Capítulo 4}

\section{Métodos de Solução}

O uso de programação inteira cresceu significantemente nas últimas décadas. A evolução das ferramentas computacionais juntamente com a criação de novas técnicas de solução foram as responsáveis por esse crescimento. Há pouco mais de vinte anos, computadores de grande porte eram capazes de resolver exemplares com até 100 variáveis inteiras. Hoje, encontram-se soluções de boa qualidade para exemplares com milhares de variáveis inteiras, em tempo computacional aceitável, em micro-computadores. O pacote CPLEX é capaz de resolver com bastante eficiência problemas de programação linear inteira, de programação inteira mista e de programação linear de grande porte.

Para avaliar a dificuldade de solução do problema de planejamento de estoque de água em reservatórios foi realizado um estudo utilizando o pacote CPLEX.

Para resolver problemas de programação linear inteira e programação linear inteira mista, o CPLEX usa o método de enumeração implícita. Para um melhor aproveitamento do pacote CPLEX é necessário entender o método utilizado para a resolução dos problemas.

Para resolver o modelo proposto propomos uma heurística baseada na intuição sobre o problema estudado. Basicamente a heurística procura manter os reservatórios com estoque de água no início do horário de ponta (de alto custo de energia), e durante o horário de ponta, para evitar ligar as bombas de captação, caso seja necessário, busca transferir água entre os reservatórios e, se ainda assim as demandas não forem atendidas liga-se a bomba de captação.

Em seguida apresentamos o método de enumeração implícita e a heurística proposta. 


\subsection{O método de enumeração implícita}

Explicaremos brevemente o algoritmo de enumeração implícita, baseado em Wolsey (2006).

O pacote CPLEX, assim como a maioria dos pacotes que resolvem problemas de programação inteira, utiliza relaxação linear para avaliar a solução.

O método de enumeração implícita tem como princípios "divisão e conquista". A estratégia consiste em dividir o conjunto de soluções factíveis em subconjuntos menores os quais são explorados recursivamente.

Seja $(P)$ um problema linear inteiro-misto dado por:

$$
\begin{gathered}
\min f(x)=c^{t} x \\
x \in S \quad(P)
\end{gathered}
$$

Detalhamos o algoritmo de enumeração implícita, fazendo uso da relaxação linear, para este problema. Seja $(\bar{P})$ a relaxação linear do problema $(P)$ (a relaxação linear consiste em ignorar as restrições de integralidade do problema $(\mathrm{P})$ ). Seja $\bar{x}$ uma solução ótima do problema $(\bar{P})$. Se $\bar{x} \in S$, então encontramos a solução ótima de $(P)$ e o procedimento está concluído. Caso contrário, ou seja $\bar{x} \notin S$, deve haver pelo menos uma variável cuja restrição de integralidade é violada, digamos $\bar{x}_{i} \notin \mathbb{Z}^{+}$. Neste caso, faz-se uma divisão no conjunto $S$, isto é, $S$ é dividido em dois conjuntos menores: $S_{1}=\left\{x \in S\right.$ tal que $\left.x_{i} \leq\left\lfloor\overline{x_{i}}\right\rfloor\right\}$ e $S_{2}=\{x \in S$ tal que $\left.x_{i} \geq\left\lceil\overline{x_{i}}\right\rceil\right\}$. Considere os seguintes problemas:

$$
\begin{gathered}
\min f(x)=c^{t} x \\
x \in S_{i} \quad\left(P_{i}\right)
\end{gathered}
$$

para $i=1,2$.

O algoritmo de enumeração implícita pode ser representado por uma árvore, na qual o nó raiz representa o problema inteiro-misto original e os nós descendentes subseqüentes representam os subproblemas (Figura 4.1).

Qualquer solução factível do problema $\left(P_{1}\right)$ fornece um limitante superior para a solução ótima do problema original $\left(z_{1}^{\text {sup }}\right)$, o mesmo ocorre para qualquer solução factível do problema $\left(P_{2}\right)\left(z_{2}^{\text {sup }}\right)$. Seja $z^{\text {melhor }}=\min \left\{z_{1}^{\text {sup }}, z_{2}^{\text {sup }}\right\}$ denominada de solução incumbente.

Exploraremos a região $S_{1}$. Seja $\left(\overline{P_{1}}\right)$ a relaxação linear do problema $\left(P_{1}\right)$ e $\overline{x^{1}}$ uma solução ótima de $\left(\overline{P_{1}}\right)$, o valor da função objetivo neste ponto fornece um limitante inferior para a solução ótima do problema original $\left(z_{1}^{\text {inf }}\right)$, isto é, uma avaliação do problema $\left(P_{1}\right)$. Se $\overline{x^{1}} \in S_{1}$ então $\overline{x^{1}}$ é uma solução ótima para o problema $\left(P_{1}\right)$ e uma solução factível para o problema $(P)$. Neste caso temos $z_{1}^{\text {sup }}=$ 


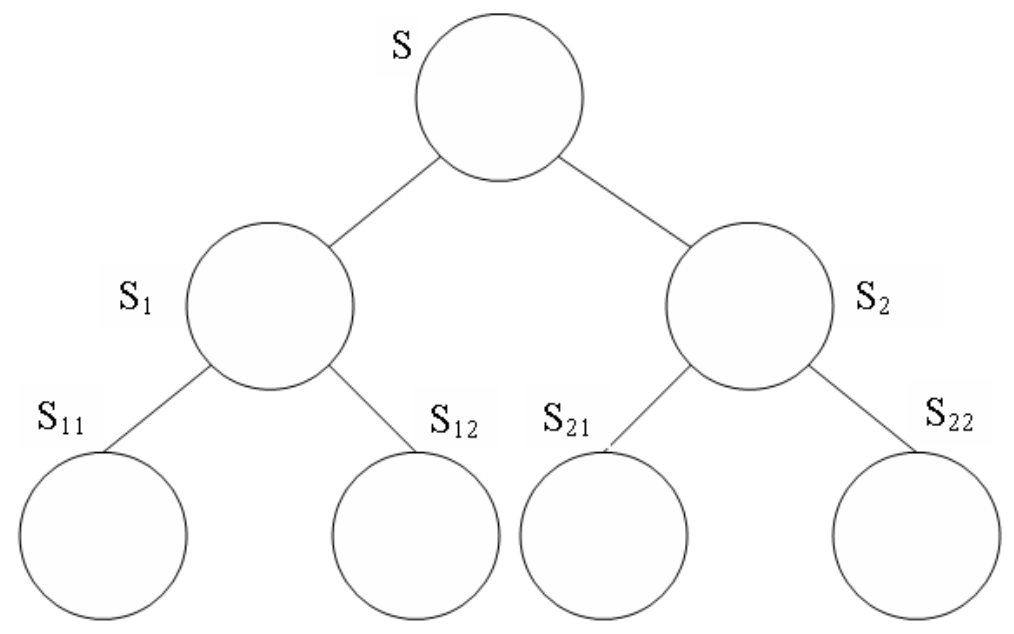

Figura 4.1: Árvore de enumeração.

$z_{1}^{\text {inf }}$ assim, deve-se atualizar a solução incumbente $z^{\text {melhor }}=\min \left\{z_{1}^{\text {sup }}, z^{\text {melhor }}\right\}$ e o nó $S_{1}$ é dito sondado (o subproblema $\left(P_{1}\right)$ não precisa mais ser explorado). Se $\overline{x^{1}} \notin S^{1}$, há duas possiblidades: se $z_{1}^{\text {inf }} \geq z^{\text {melhor }}$ o conjunto $S_{1}$ pode ser descartado (a região $S_{1}$ é implicitamente explorada); mas se $z_{1}^{\text {inf }}<z^{\text {melhor }}$, o conjunto $S_{1}$ necessita ser explorado. Neste caso, faz-se uma divisão no conjunto $S_{1}$ e repete-se o procedimento até que todos os problemas subseqüentes sejam sondados.

Da mesma maneira a região $S_{2}$ deve ser explorada.

Há casos em que o subproblema $\left(P_{i}\right)$ não precisa ser explorado (o nó pode ser sondado):

- Otimalidade: $z_{i}^{\text {sup }}=z_{i}^{i n f}$.

- O limitante inferior para o problema $\left(P_{i}\right)$ (avaliação de $\left(P_{i}\right)$ ) é maior do que a solução incumbente.

- $S_{i}=\emptyset$

Em qualquer um destes casos o nó $S_{i}$ é declarado sondado, pois todas as suas soluções factíveis estão implicitamente enumeradas.

Para que o método de enumeração implícita não se torne exaustivo é necessário acelerar o processo de sondagem e isto pode ser obtido com limitantes melhores (quanto maior o limitante inferior, mais fácil é sondar um nó).

Para a eficiência do método precisamos ter um problema relaxado de fácil resolução que forneça limitantes inferiores de boa qualidade. Infelizmente, na prática, um problema relaxado de fácil resolução normalmente fornece um 
limitante inferior de má qualidade. Como dito anteriormente, o CPLEX usa a relaxação linear, pois um problema linear é relativamente mais fácil de resolver, porém fornece um limitante inferior nem sempre muito bom e a árvore de enumeração pode crescer exponencialmente, invibializando a resolução do problema .

\subsection{Heurística}

Nesta seção apresentamos uma heurística baseada na intuição do problema. Os períodos são classificados como: períodos críticos (os pertencentes ao horário de ponta), períodos pré-críticos (períodos fora do horário de ponta que precedem os períodos críticos) e períodos não críticos (períodos fora do horário de ponta que não precedem os períodos críticos). Para cada uma destas classificações há uma estratégia operacional definida.

Explicamos as estratégias para cada período.

\section{Estratégia Operacional Das Bombas Para os Períodos Não Críticos}

Para um período não crítico, as bombas permanecem desligadas, a menos que o nível mínimo de um resevatório j seja atingido. Neste caso, duas estratégias são analisadas e é escolhida aquela de menor custo:

- Ligar a bomba do reservatório no período o suficiente para satisfazer a demanda. Neste caso, se a bomba hidráulica não estiver ligada durante todo o período anterior haverá o custo de acionamento da bomba.

- Satisfazer a demanda do período durante o último período precedente no qual a bomba estava ligada. Neste caso, não há custo de acionamento da bomba hidráulica, pois esta já estava ligada, porém, há perda de água.

Estratégia Operacional Das Bombas Para os Períodos PréCRÍticos

Nestes períodos as bombas hidráulicas são mantidas ligadas enquanto a capacidade do reservatório permitir, para armazenar água para os períodos críticos. O número de períodos pré-críticos depende da perda de água do reservatório. $\mathrm{Na}$ seção 4.2.1 detalhamos um procedimento para o cálculo dos períodos pré-críticos

Estratégia Operacional Das Bombas Para os Períodos Críticos 
Se a quantidade de água acumulada durante os períodos pré-críticos não for suficiente para satisfazer a demanda do reservatório durante todos os períodos críticos, deve-se, se possível, satisfazer a demanda deste reservatório por transferência de água vinda de outros reservatórios. Se isso não for possível então liga-se a bomba o suficiente para satisfazer a demanda deste reservatório nos períodos críticos.

A heurística consiste em cada período, para cada reservatório, verificar se este é classificado como crítico, pré-crítico ou não-crítico, e para cada classificação há um método operacional de bombeamento definido, conforme o algoritmo a seguir:

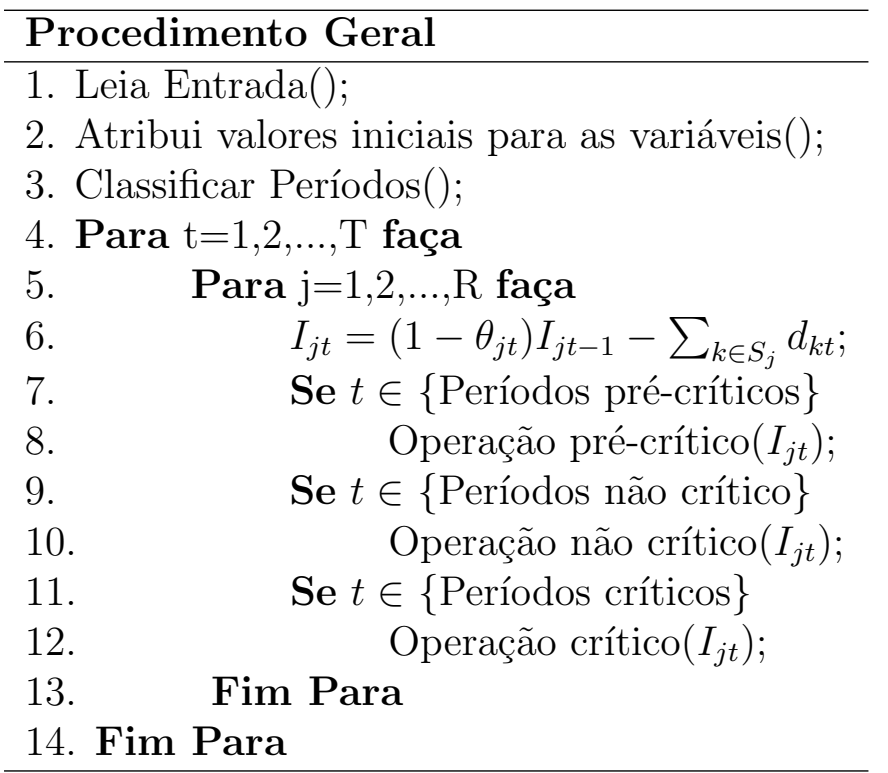

\subsubsection{Períodos Críticos, Pré-Críticos e Não Críticos}

Para classificar os períodos primeiramente verificamos quais são os períodos críticos. Não há dificuldade nisso pois conhecemos a duração de cada período e sabemos quais são os horários de ponta.

Por exemplo, em um horizonte de planejamento de $24 \mathrm{~h}$, com períodos de $1 \mathrm{~h}$, e horário de ponta compreendido das $18 \mathrm{~h}$ às $21 \mathrm{~h}$ temos que os períodos 19,20, e 21 são períodos críticos. Observe que o período 1 diz respeito ao intervalo de $0 \mathrm{~h}$ a 1h. Assim, o período 19 compreende o intervalo das $18 \mathrm{~h}$ às $19 \mathrm{~h}$.

Agora estabelecemos entre os períodos restantes quais são os períodos précríticos.

Devido às perdas de água em um reservatório, pode ser mais conveniente ligar a bomba hidráulica durante um período crítico do que bombear água em um período não-crítico muito anterior ao período crítico para usá-la no período crítico. 


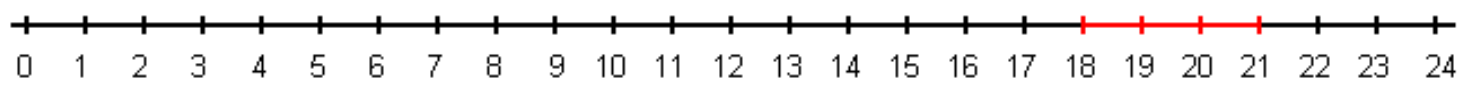

Figura 4.2: Horizonte de Planejamento de $24 \mathrm{~h}$ divido em períodos de uma hora, os períodos críticos estão em vermelho.

Por exemplo, considerando o horizonte de planejamento com a discretização dada acima, suponha que o custo de manter a bomba ligada durante uma hora seja de 30 unidades monetárias no horário não-crítico, de 60 unidades monetárias no horário crítico, e que a vazão dessa bomba seja de $300 \mathrm{~m}^{3}$ por hora, e que este reservatório tenha uma perda de água de $20 \%$ em uma hora. Assim para bombear $300 \mathrm{~m}^{3}$ de água no período 15 (período não-crítico) o custo é de 30 unidades monetárias, supondo que o reservatório estava vazio e que esta água só será usada no perído 19 temos:

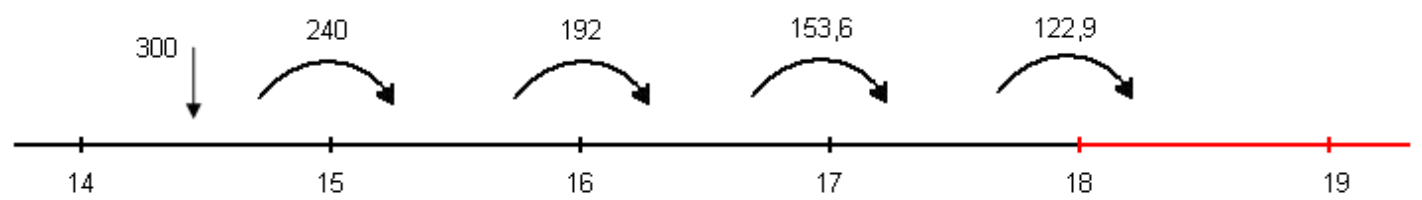

Figura 4.3: Perdas de água do período 15 ao período 19.

$$
\begin{aligned}
& I_{j 15}=300, \\
& I_{j 16}=240, \\
& I_{j 17}=192, \\
& I_{j 18}=153,6, \\
& I_{j 19}=122,9 .
\end{aligned}
$$

Ou seja, no período 19 há $122,9 \mathrm{~m}^{3}$ de água disponível, que custaram 30 unidades monetárias. Para bombear $122,9 \mathrm{~m}^{3}$ de água durante o período $19 \mathrm{o}$ custo é de 24, 6 unidades monetárias. Logo, é mais barato bombear água durante o período 19 do que armazená-la desde o período 15 para usá-la somente no período 19.

No caso de bombearmos $300 \mathrm{~m}^{3}$ de água no período 17 para ser usada no período 19 temos:

$$
I_{j 17}=300
$$




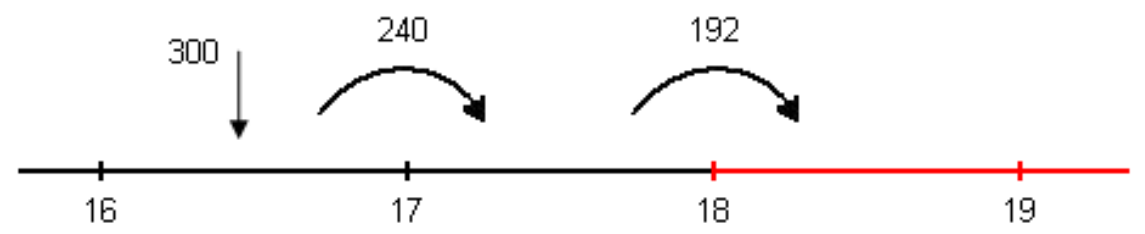

Figura 4.4: Perdas de água do período 17 ao período 19.

$$
\begin{aligned}
& I_{j 18}=240 \\
& I_{j 19}=192 .
\end{aligned}
$$

Ou seja, no período 19 há $192 m^{3}$ de água disponível, que custaram 30 unidades monetárias. Para bombear $192 \mathrm{~m}^{3}$ de água durante o período 19 o custo é de 38,4 unidades monetárias. Logo, é mais barato bombear água durante o período 17 e usá-la no período 19 do que ligar a bomba no período 19. Naturalmente, este adicional de água é limitado pela capacidade do reservatório.

Os períodos definidos como períodos pré-críticos são os períodos precedentes aos períodos críticos nos quais é conveniente bombear água e armazená-la para usá-la durante os períodos críticos. Para estabelecer estes períodos seguimos o seguinte raciocínio: se o volume bruto de água bombeada em um período não-crítico dividido pelo volume líquido dessa água (decrescido das perdas provenientes) no início do horário crítico for menor do que o preço de bombear $1 \mathrm{~m}^{3}$ de água em um período crítico dividido pelo preço de bombear $1 \mathrm{~m}^{3}$ de água em um período que está no horário fora de ponta, então este período é classificado como período pré-crítico. Para estabelecer o período pré-crítico inicial usamos o algoritmo abaixo, as variáveis $i_{j}$ retornam este valor para cada reservatório $j$. 


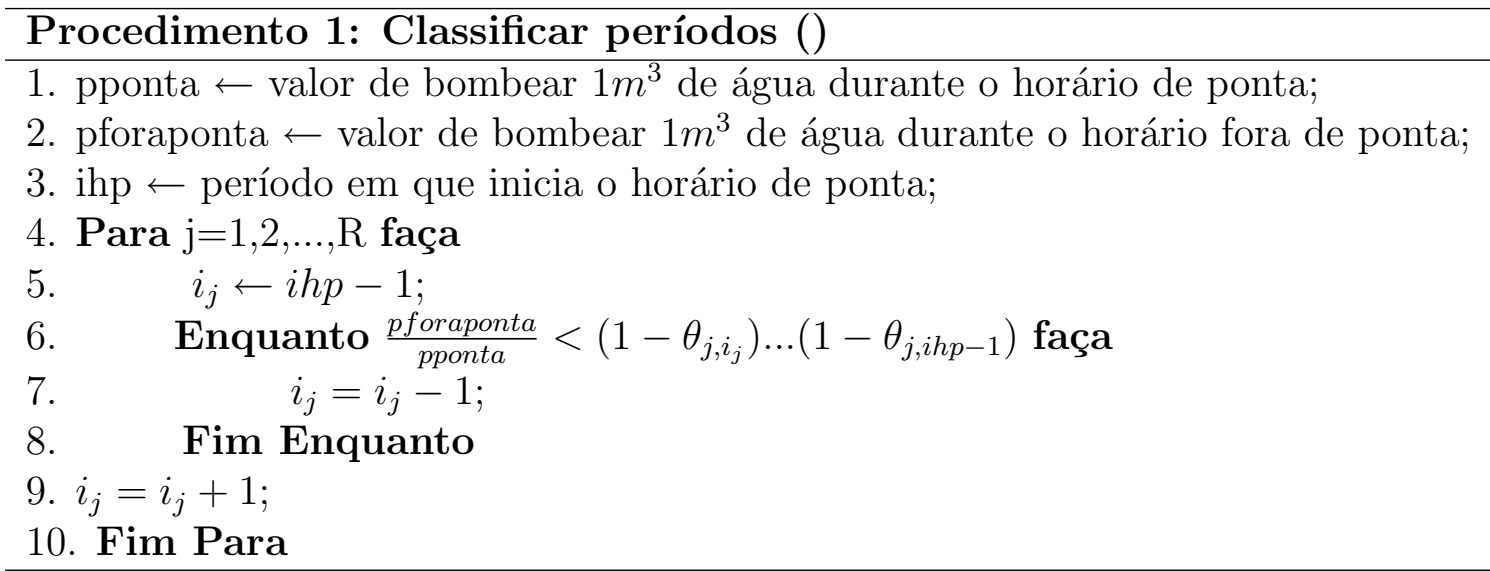

\subsubsection{Estratégia de operação bombeamento/reservação para períodos não críticos}

O planejamento, para cada reservatório, em cada período classificado como não crítico consiste em analisar separadamente cada reservatório e manter a bomba associada a este desligada se o reservatório possui estoque de água suficiente para satisfazer a demanda de água do período, respeitando o nível mínimo do reservatório. Se a quantidade de água armazenada não for suficiente para satisfazer a demanda do período então deve-se escolher a operação de menor custo:

- Acionar a bomba associada ao reservatório j o necessário para atender a demanda do período e manter o nível mínimo: $v_{j t} x_{j t}=\sum_{k \in S_{j}} d_{k t}-(1-$ $\left.\theta_{j t}\right) I_{j t}+h_{j}^{\text {min }}$ (veja equação $(3.2) \operatorname{com} I_{j t}=h_{j}^{\text {min }}$ );

- Reservar água de períodos anteriores $(t-1, t-2, \ldots)$ nos quais a bomba estava ligada.

A primeira estratégia paga o custo de acionar a bomba e a segunda paga o custo subjacente à perda de água.

Exemplificamos esta estratégia de bombeamento para um reservatório com capacidade de $1000 \mathrm{~m}^{3}$ e nível mínimo pré-estabelecido em $270 \mathrm{~m}^{3}$, com períodos de $1 \mathrm{~h}$. Considere a vazão da bomba associada a esse reservatório como sendo de $300 m^{3}$ por hora e o custo de manter esta bomba ligada durante uma hora sendo de 30 unidades monetárias para os períodos não críticos e de 60 unidades monetárias para os períodos críticos, e o custo de acionar essa bomba sendo de 1 unidade monetária. Suponha que o reservatório tenha uma perda de $10 \%$ do seu volume por período. Seja $370 \mathrm{~m}^{3}$ o nível inicial do reservatório no início do horizonte de planejamento e as demanda para os períodos 1,2,3 e 4 são de $33 m^{3}, 90 m^{3}, 50 m^{3}, 80 m^{3}$ respectivamente. 
Assim, supondo a bomba desligada no período 1, o nível do reservatório no final desse período será dado pelo volume inicial decrescido das perdas de água e da demanda do período, ou seja: (por simplificação omitimos o índice do reservatório)

$$
I_{1}=0,9 \cdot 370-33=300 .
$$

Assim a bomba deve ser mantida desligada e os valores das variáveis para este período são:

$$
I_{1}=300 m^{3}, x_{1}=0 .
$$

Analisamos agora o $2^{\circ}$ período. Supondo a bomba desligada no período 2 , o nível do reservatório no final desse período será dado pelo volume no final do período 1 decrescido das perdas de água e da demanda do período 2, ou seja:

$$
I_{2}=0,9 \cdot 300-90=180 .
$$

Se a bomba permanecer desligada o nível do reservatório no final do período 2 será menor do que o nível mínimo pré-estabelecido, assim a bomba deve ser acionada o suficiente para satisfazer a demanda do período e as perdas de água conseqüentes do volume de água no reservatório, e como esta não foi ligada em nenhum dos períodos desde o início do horizonte de planejamento deve ser ligada neste período. A fração do período que a bomba deve permanecer ligada é obtida da equação de balanceamento de estoque, seja $x_{2}$ este valor:

$$
\begin{gathered}
0,9 \cdot 300+x_{2} \cdot 300-90=270, \\
x_{2}=0,3 .
\end{gathered}
$$

Assim, no período 2 a bomba deve permanecer ligada por 0,3 partes do período, e os valores das variáveis para esse período são:

$$
I_{2}=270 m^{3}, x_{2}=0,3 \text {. }
$$

Analisamos agora o $3^{\circ}$ período. Supondo a bomba desligada no período 3 , o nível do reservatório no final desse período será dado pelo volume no final do período 2 decrescido das perdas de água e da demanda do período 3, ou seja:

$$
I_{3}=0,9 \cdot 270-50=193 .
$$

Se a bomba permanecer desligada o nível do reservatório no final do período 3 será menor do que o nível mínimo pré-estabelecido, assim a bomba deve ser acionada. Como a bomba estava ligada durante o período 2, devemos decidir qual operação é mais vantajosa: armazenar água durante o período 2 e não ligar a bomba durante o período 3, neste caso não há o custo de acionar a bomba, pois esta já estava ligada; ou acionar a bomba no período 3 a fim de satisfazer a demanda deste período. 
Calculamos o custo nestes dois casos e escolhemos a operação de menor custo.

A fração do período 2 que a bomba deve permanecer ligada a fim de satisfazer a demanda do período 3 e as perdas decorrentes é dada pela equação abaixo, onde $\overline{x_{2}}$ representa este valor:

$$
\begin{gathered}
\left(0,9 \cdot 300+\left(0,3+\overline{x_{2}}\right) \cdot 300-90\right) \cdot 0,9-50=270, \\
\overline{x_{2}}=0,2852
\end{gathered}
$$

O custo desta operação é aproximadamente $0,2852 \cdot 30=8,556$.

A fração do período 3 que a bomba deve permanecer ligada a fim de satisfazer a demanda deste período e as perdas de água decorrentes é dada pela equação abaixo, onde $x_{3}$ representa este valor:

$$
\begin{gathered}
0,9 \cdot 270+x_{3} \cdot 300-50=270 \\
x_{3}=0,2567
\end{gathered}
$$

O custo dessa operação é $1+0,2567 \cdot 30=8,7$.

Assim, a operação mais vantajosa é armazenar água no período 2 para o período 3 , as variáveis relacionadas ao período 2 devem então ser atualizadas:

$$
\begin{gathered}
x_{2}=0,3+0,2852=0,5852, \\
I_{2}=0,9 \cdot 300+0,5852 \cdot 300-90=355,56 \leq 1000 .
\end{gathered}
$$

E as variáveis relacionadas ao período 3 são dadas por:

$$
\begin{gathered}
x_{3}=0, \\
I_{3}=0,9 \cdot 355,56-50=270 .
\end{gathered}
$$

Analisamos agora o $4^{\circ}$ período. Supondo a bomba desligada no período 4, o nível do reservatório no final desse período será dado pelo volume no final do período 3 decrescido das perdas de água e da demanda do período 4, ou seja:

$$
I_{4}=0,9 \cdot 270-80=163 .
$$

Se a bomba permanecer desligada o nível do reservatório no final do período 4 será menor do que o nível mínimo pré-estabelecido, assim a bomba deve ser acionada. Como a bomba estava ligada durante o período 2, devemos decidir qual operação é mais vantajosa: armazenar água durante o período 2 e não ligar a bomba durante o período 4, neste caso não há o custo de acionar a bomba, pois esta já estava ligada; ou acionar a bomba no período 4 a fim de satisfazer a demanda deste período. 
Calculamos o custo nestes dois casos e escolhemos a operação de menor custo.

A fração do período 2 que a bomba deve permanecer ligada a fim de satisfazer a demanda do período 4 e as perdas decorrentes é dada pela equação abaixo, e $\overline{\overline{x_{2}}}$ representa este valor:

$$
\begin{gathered}
{\left[\left(0,9 \cdot 300+\left(0,5852+\overline{\overline{x_{2}}}\right) \cdot 300-90\right) \cdot 0,9-50\right] \cdot 0,9-80=270,} \\
\overline{\overline{x_{2}}}=0,44031 .
\end{gathered}
$$

Observe que neste caso o novo valor para a variável $x_{2}$ será $0,5852+0,4403$ que é um número maior que 1 , assim a capacidade do período não permite armazenar água o suficiente para satisfazer toda a demanda do período 4. Assim, o restante da demanda do período 4 deverá ser satisfeita no período 3. Pela equação abaixo encontramos a fração do período 3 que a bomba precisa permanecer ligada, $x_{3}$ representa este valor,

$$
\begin{gathered}
{\left[(0,9 \cdot 300+300-90) \cdot 0,9-50+300 \cdot x_{3}\right] \cdot 0,9-80=270} \\
x_{3}=0,023 .
\end{gathered}
$$

Assim, o custo desta operação é dado pela soma dos custos de satisfazer a demanda do período 4 no períodos 2 e $3:(1-0,5852 \cdot 30+0,023) \cdot 30=13,13$.

Avaliamos agora o custo de acionar a bomba no período 4. A fração do período 4 que a bomba deve permanecer ligada a fim de satisfazer a demanda do período as perdas decorrentes é dada pela equação abaixo, e $x_{4}$ representa este valor:

$$
\begin{gathered}
0,9 \cdot 270+300 \cdot x_{4}-80=270, \\
x_{4}=0,357 .
\end{gathered}
$$

O custo dessa operação é $1+0,357 \cdot 30=11,7$.

Assim, a operação mais vantajosa é ligar a bomba no período 4, as variáveis para esse período são:

$$
I_{4}=270, x_{4}=0,357 .
$$

Seguindo este raciocínio, desenvolvemos o seguinte algoritmo para os períodos classificados como não críticos. 


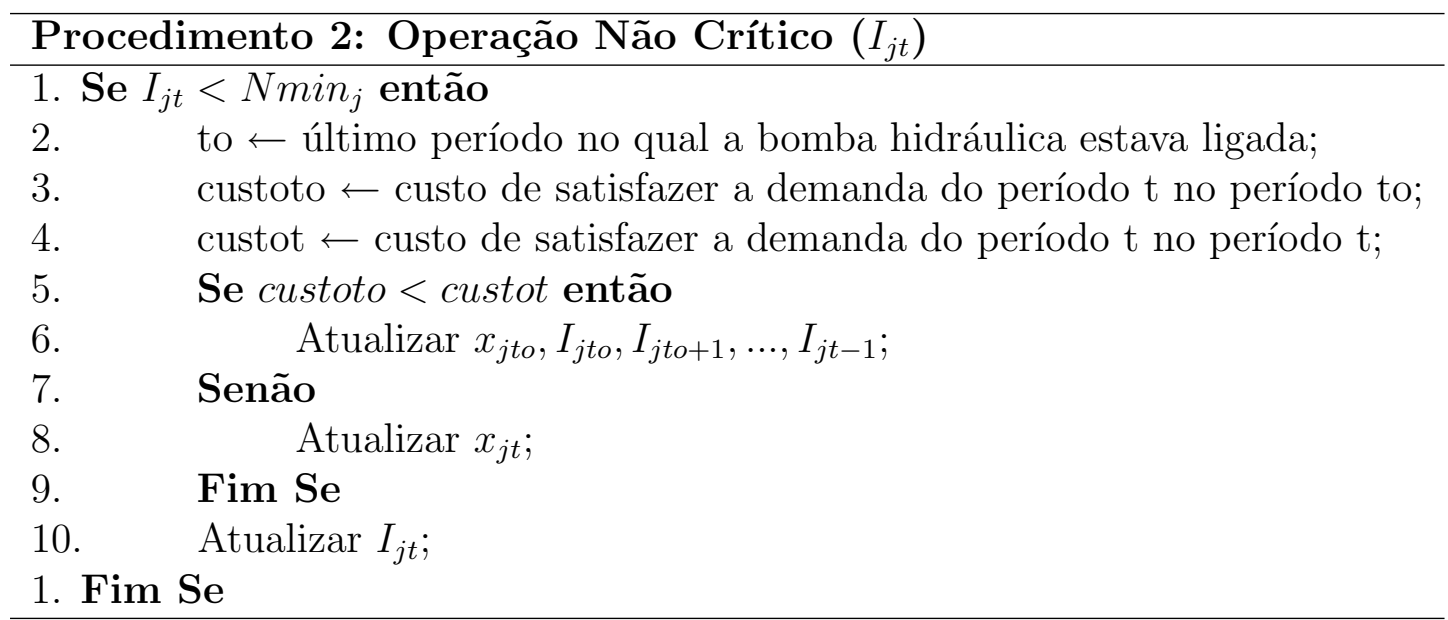

\subsubsection{Estratégia de operação bombeamento/reservação para períodos pré-críticos}

Nestes períodos, se a capacidade do reservatório permitir, as bombas hidráulicas são mantidas ligadas para armazenar água para os períodos críticos.

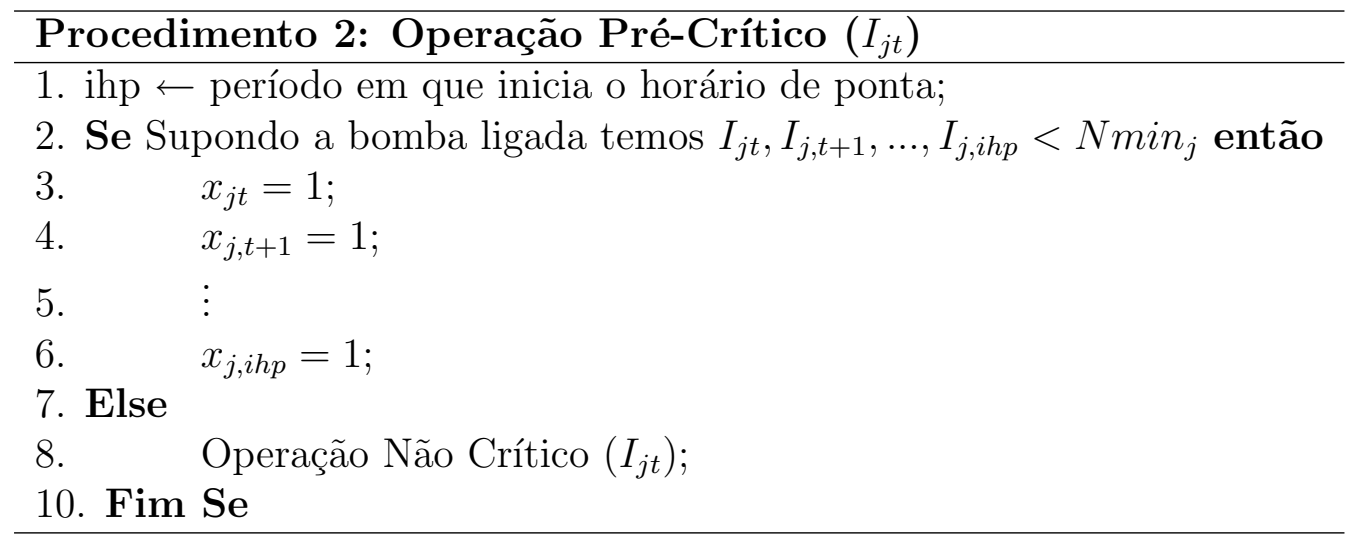

\subsubsection{Estratégia de operação bombeamento/reservação para períodos críticos}

Primeiro exemplificamos o procedimento heurístico para os períodos classificados como críticos, em seguida detalhamos o algoritmo.

Para isso tomemos um sistema de abastecimento composto por quatro reservatórios, como o descrito abaixo, onde os círculos representam os reservatórios, os arcos representam as adutoras e as setas indicam o sentido da transferência.

Note que não é possível transferir água diretamente entre os reservatórios $1 \mathrm{e}$ 4, e entre os reservatórios 3 e 2. Mas a transferência indireta ocorre na prática e 


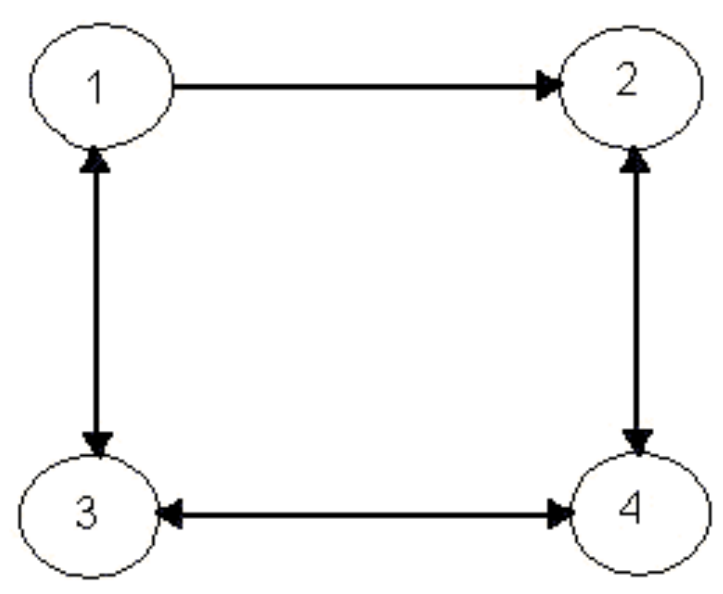

Figura 4.5: Sistema de abastecimento com 4 reservatórios.

deve ser considerada.

Como podemos observar na Figura 4.5, é possível representar um sistema de abastecimento por um grafo.

Consideramos que a capacidade do reservatório 1 é de $900 \mathrm{~m}^{3}$, do reservatório 2 é $1000 \mathrm{~m}^{3}$, do reservatório 3 é $600 \mathrm{~m}^{3}$ e do reservatório 4 é $800 \mathrm{~m}^{3}$, e o nível mínimo destes reservatórios é $270 \mathrm{~m}^{3}$.

A vazão de todas as bombas de transferência é de $60 \mathrm{~m}^{3}$ por hora com custo de 3 unidades monetárias. A vazão das bombas hidráulicas associadas a cada reservatório é $300 \mathrm{~m}^{3}$ por hora com custo de 60 unidades monetárias para os períodos críticos. A perda neste sistema é da ordem de $10 \%$ do volume do reservatório em uma hora.

Consideramos um horizonte de planejamento de $24 \mathrm{~h}$ dividido em períodos de uma hora, e os períodos 19, 20 e 21 os períodos críticos. Suponha que já foi feito o planejamento até o período 18 e no final deste período o nível do reservatório 1 é $873 m^{3}$, do reservatório 2 é $900 m^{3}$, do reservatório 3 é $600 m^{3}$ e do reservatório 4 é $800 \mathrm{~m}^{3}$. Explicamos a estratégia adotada para os períodos 19, 20 e 21. A Tabela 4.1 apresenta a demanda para estes períodos em cada reservatório.

Primeiramente, para cada período, analisamos cada reservatório, verificando se o seu estoque de água é suficiente para satisfazer a sua demanda durante a faixa horária crítica. Caso não seja possível, tentamos satisfazer a demanda deste reservatório por transferência de água de outros reservatórios. Se ainda assim, a demanda do reservatório não for satisfeita, liga-se a bomba hidráulica associada a 


\begin{tabular}{|l|c|c|c|}
\hline & Período 19 & Período 20 & Período 21 \\
\hline Reservatório 1 & $135 m^{3}$ & $99 m^{3}$ & $111 m^{3}$ \\
\hline Reservatório 2 & $176 m^{3}$ & $104 m^{3}$ & $100 m^{3}$ \\
\hline Reservatório 3 & $143 m^{3}$ & $128 m^{3}$ & $129 m^{3}$ \\
\hline Reservatório 4 & $148 m^{3}$ & $100 m^{3}$ & $103 m^{3}$ \\
\hline
\end{tabular}

Tabela 4.1: Demandas.

este reservatório, o necessário para satisfazer a demanda do período.

Supondo a bomba 1 desligada durante o período 19, no final deste período o nível do reservatório 1 será o estoque de água no final do período 18 decrescido das perdas decorrentes e da demanda deste reservatório, ou seja:

$$
I_{1,19}=0,9 \cdot 873,0-135,0=650,7 .
$$

Assim, não há necessidade de acionarmos qualquer bomba para satisfazer a demanda deste reservatório no período 19.

Supondo a bomba 2 desligada, no final do período 19 o nível do reservatório 2 será:

$$
I_{2,19}=0,9 \cdot 900-176=634 .
$$

Assim, não há necessidade de acionarmos qualquer bomba para satisfazer a demanda deste reservatório no período 19.

Supondo a bomba 3 desligada, no final do período 19 o nível do reservatório 3 será:

$$
I_{3,19}=0,9 \cdot 600-143=397 .
$$

Assim, não há necessidade de acionarmos qualquer bomba para satisfazer a demanda deste reservatório no período 19.

Supondo a bomba 4 desligada, no final do período 19 o nível do reservatório 4 será:

$$
I_{4,19}=0,9 \cdot 800-148=572 .
$$

Assim, não há necessidade de acionarmos qualquer bomba para satisfazer a demanda deste reservatório no período 19.

Assim, as variáveis relacionadas ao período 19 são:

$$
\begin{gathered}
I_{1,19}=650,7, x_{1,19}=0, z_{3,1,19}=0, \\
I_{2,19}=634, x_{2,19}=0, z_{1,2,19}=0, z_{4,2,19}=0, \\
I_{3,19}=397, x_{3,19}=0, z_{1,3,19}=0, z_{4,3,19}=0, \\
I_{4,19}=572, x_{4,19}=0, z_{3,4,19}=0, z_{2,4,19}=0 .
\end{gathered}
$$


Analisamos agora o $20^{\circ}$ período.

Supondo a bomba 1 desligada durante o $20^{\circ}$ período, o nível do reservatório 1 no final deste período será:

$$
I_{1,20}=0,9 \cdot 650,7-99=486,63 .
$$

Supondo a bomba 2 desligada durante o $20^{\circ}$ período, o nível do reservatório 2 no final deste período será:

$$
I_{2,20}=0,9 \cdot 634-104=466,6 .
$$

Supondo a bomba 3 desligada durante o $20^{\circ}$ período, o nível do reservatório 3 no final deste período será:

$$
I_{3,20}=0,9 \cdot 397-128=229,3 .
$$

Se nenhuma decisão for tomada o nível do reservatório 3 será menor que o nível mínimo pré-estabelecido. Assim, tentaremos atender a necessidade deste reservatório por transferência de água de outros reservatórios. Para isso calculamos a quantidade de água que este reservatório precisa receber neste período, esta quantidade é dada pelo nível mínimo estabelecido para este reservatório menos o estoque de água que o reservatório teria mantendo-se as bombas associadas a este desligadas, esta quantidade é dada por:

$$
270-229,3=40,7 .
$$

Assim, este reservatório precisa receber $40,7 \mathrm{~m}^{3}$ de água no período 20.

Agora verificamos quais reservatórios podem enviar água para o reservatório 3, direta ou indiretamente, e entre estes escolher o reservatório no qual o custo de transferir água para o reservatório 3 é menor. Para isso usamos o algoritmo de Floyd, que nos fornece as distâncias mínimas entre todos os pares de nós de um grafo. A matriz $D$ abaixo apresenta todas as menores distâncias entre os pares de nós do grafo da Figura 4.5 e fazemos uso da matriz $P$ para recuperar o caminho mínimo entre dois nós. Estas matrizes foram obtidas pelo algoritmo de Floyd (para mais detalhes sobre este algoritmo veja o apêndice).

$$
\begin{aligned}
& D=\left[\begin{array}{llll}
0 & 3 & 3 & 6 \\
9 & 0 & 6 & 3 \\
3 & 6 & 0 & 3 \\
6 & 3 & 3 & 0
\end{array}\right] \\
& P=\left[\begin{array}{llll}
1 & 1 & 1 & 2 \\
3 & 2 & 4 & 2 \\
3 & 1 & 3 & 3 \\
3 & 4 & 4 & 4
\end{array}\right]
\end{aligned}
$$


Da matriz $D$, o reservatório 3 pode receber água do reservatório 1 com custo de 3 unidades monetárias por hora, do reservatório 4 com custo de 3 unidades monetárias por hora e do reservatório 2 com custo de 6 unidades monetárias por hora (neste caso a transferência é indireta, o reservatório 2 envia água para o reservatório 4 e este reenvia para o reservatório 3).

Assim, os reservatórios que podem enviar água para o reservatório $3 \mathrm{com}$ menor custo são os reservatórios 1 e 4 . Verificamos quais destes reservatórios apresentam estoque de água suficiente para satisfazer sua demanda própria e transferir água para o reservatórios 3 sem acionar sua bomba hidráulica.

A quantidade de água que o reservatório 1 pode enviar no período 20 é dada pela equação abaixo, e $z$ representa esta quantidade:

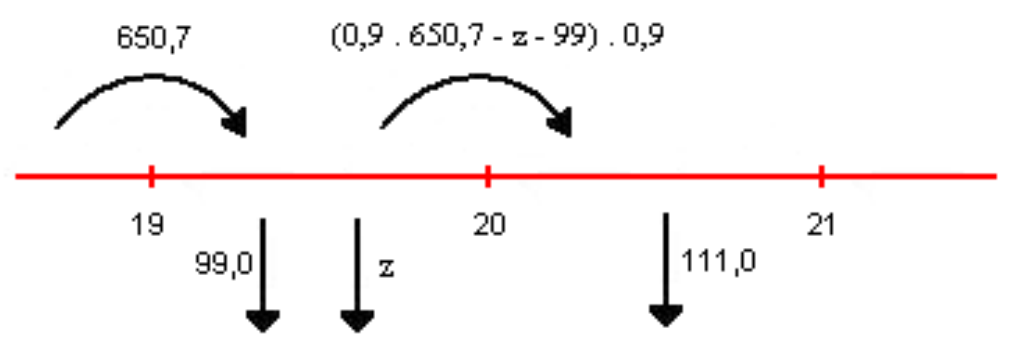

Figura 4.6: Quantidade de água que o reservatório 1 pode enviar no período 20.

$$
\begin{gathered}
(0,9 \cdot 650,7-z-99) \cdot 0,9-111=270 \\
z=63,29
\end{gathered}
$$

Assim, o reservatório 1 pode enviar até $63,29 \mathrm{~m}^{3}$ de água durante o período 20 . A quantidade de água que este reservatório envia para o reservatório 3 é dado pelo valor mínimo entre a quantidade de água que seu estoque permite enviar, a vazão da bomba de transferência do reservatório 1 para o reservatório 3 no período 20 e a quantidade de água que o reservatório 1 precisa receber neste período, ou seja:

$$
\min (63,29 ; 60 ; 40,7)=40,7 .
$$

Assim, o volume de água dos reservatório 1 e 3, no período 20 é atualizado:

$$
\begin{gathered}
I_{1,20}=0,9 \cdot 650,7-99-40,7=445,93 . \\
I_{3,20}=0,9 \cdot 397-128+40,7=270 .
\end{gathered}
$$


Pela matriz $P$ vemos que o reservatório 1 envia água diretamente para o reservatório 3. Assim, a variável de transferência assume o seguinte valor:

$$
z_{1,3,20}=\frac{40,7}{60}=0,678 \text {. }
$$

Como a demanda do reservatório 3 no período 20 já foi satisfeita não é necessário analisarmos os demais reservatórios que podem enviar para este reservatório.

Analisamos agora o reservatório 4 no período 20.

Supondo a bomba 4 desligada durante o período 20, o nível do reservatório 4 no final deste período será:

$$
I_{4,20}=0,9 \cdot 572-100=414,8 .
$$

Assim, as variáveis relacionadas ao período 20 assumem os seguintes valores:

$$
\begin{gathered}
I_{1,20}=445,93, x_{1,20}=0, z_{3,1,20}=0, \\
I_{2,20}=466,6, x_{2,20}=0, z_{1,2,20}=0, z_{4,2,20}=0, \\
I_{3,20}=270, x_{3,20}=0, z_{1,3,20}=0,678, z_{4,3,20}=0, \\
I_{4,20}=414,8, x_{4,20}=0, z_{2,4,20}=0, z_{3,4,20}=0 .
\end{gathered}
$$

Analisamos agora o $21^{\circ}$ período.

Supondo a bomba 1 desligada durante o $21^{\circ}$ período, o nível do reservatório 1 no final deste período será:

$$
I_{1,21}=0,9 \cdot 445,93-111=290,337 .
$$

Supondo a bomba 2 desligada durante o $21^{\circ}$ período, o nível do reservatório 2 no final deste período será:

$$
I_{2,21}=0,9 \cdot 466,6-100=319,94 .
$$

Supondo a bomba 3 desligada durante o $21^{\circ}$ período, o nível do reservatório 3 no final deste período será:

$$
I_{3,21}=0,9 \cdot 270-129=114
$$

Novamente tentamos atender a necessidade de água deste reservatório por transferência de água de outros reservatórios. Para isso calculamos a quantidade de água que este reservatório precisa receber neste período:

$$
270-114=156 .
$$


Assim, este reservatório precisa receber um adicional de $156 \mathrm{~m}^{3}$ de água no período 21 .

Novamente consultamos a matriz $D$ e vemos que os reservatórios que podem enviar água para o reservatório 3 com menor custo são os reservatórios 1 e 4, verificaremos quais destes reservatórios apresentam estoque de água suficiente para satisfazer sua demanda própria e transferir água para o reservatório 3, sem acionar sua bomba hidráulica.

A quantidade de água que o reservatório 1 pode enviar no período 21 é dada pela equação abaixo, onde $\mathrm{z}$ representa esta quantidade:

$$
\begin{gathered}
0,9 \cdot 445,93-z-111=270 \\
z=20,337 .
\end{gathered}
$$

Assim, o reservatório 1 pode enviar até $20,337 \mathrm{~m}^{3}$ de água durante o período 21. Logo, a quantidade de água que este reservatório envia para o reservatório 3 é dado por:

$$
\min (20,337 ; 60 ; 156)=20,337 .
$$

O volume de água do reservatório 1 , no período 21 é atualizado:

$$
I_{1,21}=0,9 \cdot 445,93-111-20,337=270 .
$$

Como o reservatório 1 envia toda a água que lhe sobra, este não pode transferir água para nenhum outro reservatório, a matriz $D$ é então atualizada:

$$
D=\left[\begin{array}{cccc}
0 & \infty & \infty & \infty \\
9 & 0 & 6 & 3 \\
3 & 6 & 0 & 3 \\
6 & 3 & 3 & 0
\end{array}\right]
$$

Pela matriz $P$, o reservatório 1 envia água diretamente para o reservatório 3. Assim, a variável de transferência relacionada ao reservatório 3 no período 21 assume o seguinte valore:

$$
z_{1,3,21}=\frac{20,337}{60}=0,33895
$$

A demanda do reservatório 3 ainda não foi satisfeita, abaixo calculamos a quantidade de água que este reservatório ainda precisa receber:

$$
156-20,337=135,663 .
$$

Tentamos satisfazer a demanda deste reservatório por transferência de água de outro reservatório. Consultando a matriz $D$, vemos que a melhor opção é tentar satisfazer a demanda do reservatório 3 pelo reservatório 4 . 
A quantidade de água que o reservatório 4 pode enviar no período 21 é dada pela equação abaixo, em que $z$ representa esta quantidade.

$$
\begin{gathered}
0,9 \cdot 414,8-z-100=270 \\
z \simeq 0 .
\end{gathered}
$$

Assim, o reservatório 4 não possui estoque de água o suficiente para enviar água para qualquer reservatório nesta faixa horária. A matriz $D$ é novamente atualizada.

$$
D=\left[\begin{array}{cccc}
0 & \infty & \infty & \infty \\
9 & 0 & 6 & 3 \\
3 & 6 & 0 & 3 \\
\infty & \infty & \infty & 0
\end{array}\right]
$$

Consultando novamente a matriz $D$ vemos que o reservatório 2 pode enviar água para o reservatório 3 .

A quantidade de água que o reservatório 2 pode enviar no período 21 é dada pela equação abaixo, em que $z$ representa esta quantidade.

$$
\begin{gathered}
0,9 \cdot 466,6-z-103=270 \\
z=49,94 .
\end{gathered}
$$

Assim, o reservatório 2 pode enviar até $49,94 \mathrm{~m}^{3}$ de água durante o período 21. Logo, a quantidade de água que este reservatório envia para o reservatório 3 é dado por:

$$
\min (49,94 ; 60 ; 135,663)=49,94 .
$$

Assim, o volume de água do reservatório 2 é atualizado:

$$
I_{2,21}=0,9 \cdot 466,6-103-49,94=270 .
$$

Pela matriz $P$, o reservatório 2 envia água para o reservatório 3 indiretamente, ou seja, o reservatório 2 envia água para o reservatório 4, e o reservatório 4 envia água para o reservatório 3. Assim as variáveis de transferência assumem os seguintes valores:

$$
\begin{aligned}
& z_{2,4,21}=\frac{49,94}{60}=0,832, \\
& z_{4,3,21}=\frac{49,94}{60}=0,832 .
\end{aligned}
$$

Como o reservatório 2 envia toda a água que lhe sobrava, este não pode transferir água para nenhum outro reservatório, a matriz $D$ é então atualizada:

$$
D=\left[\begin{array}{cccc}
0 & \infty & \infty & \infty \\
\infty & 0 & \infty & \infty \\
3 & 6 & 0 & 3 \\
\infty & \infty & \infty & 0
\end{array}\right]
$$


A demanda do reservatório 3 ainda não foi satisfeita, este reservatório precisa receber mais água, a equação abaixo representa esta quantidade:

$$
135,663-49,94=85,723 .
$$

Consultamos novamente a matriz $D$ e percebemos que nenhum reservatório pode enviar água para o reservatório 3, e uma opção para suprir a demanda do reservatório 3 é acionar a bomba hidráulica associado ao reservatório neste período, assim:

$$
x_{3,21}=\frac{85,723}{300}=0,286 .
$$

O volume de água do reservatório 3 é então atualizado:

$$
I_{3,21}=0,9 \cdot 270-129+20,337+49,94+85,723=270
$$

Para o reservatório 4 , supondo a bomba 4 desligada durante o $21^{\circ}$ período, o nível do reservatório 4 no final deste período será:

$$
I_{4,21}=0,9 \cdot 414,8-103=270 \text {. }
$$

Assim, as variáveis relacionadas ao período 21 assumem os seguintes valores:

$$
\begin{gathered}
I_{1,21}=270, x_{1,21}=0, z_{3,1,21}=0, \\
I_{2,21}=270, x_{2,21}=0, z_{1,2,21}=0, z_{4,2,21}=0 \\
I_{3,21}=270, x_{3,21}=0,286, z_{1,3,21}=0,33895, z_{4,3,21}=0,832, \\
I_{4,21}=270, x_{4,21}=0, z_{2,4,21}=0,832, z_{3,4,21}=0 .
\end{gathered}
$$

Seguindo este raciocínio desenvolvemos o algoritmo a seguir: 
Procedimento 3: Operação Crítico $\left(I_{j t}\right)$

1. Se $t=$ inicio do horário crítico então

2. Determina matriz $D=\left(D_{m n}\right)$ - algoritmo de Floyd;

3. Fim Se

4. Se $I_{j t}<h_{j}^{\text {min }}$ então

5. $\quad j 1=\min \left(D_{1 j}, D_{2 j}, \ldots, D_{R j}\right)$;

6. $\quad$ aresprecisa $\leftarrow$ quantidade de água que o reservatório j precisa receber no período;

7. $\quad$ Enquanto aresprecisa $>0$ e $j 1 \neq \infty$ faça

8. $\quad$ resenvia $\leftarrow \ell$, tal que $D_{\ell j}=\min \left(D_{1 j}, D_{2 j}, \ldots, D_{R j}\right)$;

9. $\quad$ qarespodeenviar $\leftarrow$ quantidade de água que o reservatório $\ell$ pode transferir;

10. Se qarespodeenviar $>0$ então

11. Atualizar $z_{\ell, i_{1}, t}, z_{i_{1}, i_{2}, t}, \ldots, z_{i_{n}, j, t}$;

12. Se Reservatório $\ell$ envia toda água lhe sobra então

13. Atualizar matriz D: $D_{\ell k}=\infty$ para $k \neq \ell$;

$14 . \quad$ Fim Se

15. Atualizar $I_{\text {resenvia, },}, I_{j t}$, aresprecisa;

16. $\quad$ Fim Se

17. $\quad j 1=\min \left(D_{1 j}, D_{2 j}, \ldots, D_{R j}\right)$;

18. Fim Enquanto

19. Se aresprecisa $>0$ então

20. $\quad x_{j t}=\frac{\text { aresprecisa }}{v_{j t}}$;

21. $\quad$ Fim Se

22. Fim Se 


\section{Capítulo 5}

\section{Experimentos Computacionais}

\subsection{Gerador de exemplares}

Para validar o modelo proposto (3.1)-(3.9) e a eficiência da heurística, foi implementado em linguagem $\mathrm{C}$ um gerador de exemplares.

O programa gera exemplares para um horizonte de planejamento de 2 dias, divididos em períodos de uma hora, de modo que o horizonte de planejamento possui 48 períodos.

O custo de manter a bomba ligada durante os períodos críticos e os períodos não críticos é diferenciado e são dados de entrada do programa. Além disso, o número de reservatórios, suas capacidades, as ligações existentes entre estes, o custo de acionar cada bomba (setup) e o custo de transferência entre os reservatórios também são dados de entrada do programa. Dessa maneira, exemplares com diferentes características podem ser gerados.

O programa gera dois arquivos, um arquivo com extensão .lp, com a estrutura requerida pelo pacote CPLEX, e um arquivo com extensão .txt, com a estrutura de acordo com a implementação da heurística.

Para os testes computacionais foram gerados diferentes exemplares. A seguir descrevemos as principais características de cada classe de exemplares.

\subsection{1 $\quad 1^{\text {a }}$ Classe de Exemplares}

Para estes exemplares consideramos 3 reservatórios. Os volumes mínimos e máximos de cada reservatório são apresentados na Tabela 5.1.

Os volumes iniciais dos reservatórios foram tomados como sendo de $500 \mathrm{~m}^{3}$.

Foram considerados três poços, cada um associado a um reservatório e a uma bomba de captação. A vazão das bombas é de $300 \mathrm{~m}^{3}$ por hora. O custo de manter ligada cada bomba durante cada um dos períodos é igual a 30 


\begin{tabular}{|c|ccc|}
\hline Volume & \multicolumn{3}{|c|}{ Reservatórios } \\
& 1 & 2 & 3 \\
\hline Mínimo & $270 m^{3}$ & $270 m^{3}$ & $270 m^{3}$ \\
\hline Máximo & $2000 m^{3}$ & $1000 m^{3}$ & $1000 m^{3}$ \\
\hline
\end{tabular}

Tabela 5.1: Volumes mínimos e máximos dos reservatórios - $1^{\mathrm{a}}$ classe de exemplares.

unidades monetárias, exceto às 18h, 19h e 20h, quando o custo é de 60 unidades monetárias (estes valores foram tomados com base na tarifa horo-sazonal azul - veja seção 3.2.1). O custo de acionar cada bomba foi arbitrado igual a 1 unidade monetária, em todos os períodos, o que é suficiente para evitar uma solução excessivamente intermitente. As demandas foram geradas uniformemente distribuídas em intervalos que representam as estimativas máximas e mínimas em cada faixa horária, o que se aproxima do comportamento real do consumo em uma cidade típica de porte médio, de acordo com os dados apresentados em Toledo et al. (2006).

\begin{tabular}{|l|l|l|l|l|l|l|l|l|l|}
\hline hora & $0-6$ & $6-7$ & $7-8$ & $8-9$ & $9-10$ & $10-11$ & $11-12$ & $12-13$ & $13-14$ \\
\hline Min & 10 & 90 & 105 & 121 & 190 & 152 & 167 & 183 & 198 \\
\hline Max & 30 & 110 & 125 & 141 & 210 & 172 & 187 & 203 & 218 \\
\hline
\end{tabular}

\begin{tabular}{|l|l|l|l|l|l|l|l|l|l|}
\hline hora & $14-15$ & $15-16$ & $16-17$ & $17-19$ & $19-20$ & $20-21$ & $21-22$ & $22-23$ & $23-24$ \\
\hline Min & 214 & 229 & 245 & 260 & 198 & 135 & 73 & 10 & 5 \\
\hline Max & 234 & 249 & 265 & 270 & 218 & 155 & 93 & 30 & 20 \\
\hline
\end{tabular}

Pode haver transferência de água entre os reservatórios: de 1 para 2, 2 para 1, 2 para 3 e 3 para 2 com custo de 3 unidades monetárias por período. Este valor foi definido considerando haver um pequeno desnível entre esses reservatórios de forma que a energia gasta pela bomba destina-se a vencer majoritariamente a dissipação viscosa. A vazão de transferência é de $60 \mathrm{~m}^{3}$ por hora. Não é permitida a transferência direta entre os reservatórios 1 e 3. O grafo apresentado na Figura 5.1 representa estes três reservatórios, as arestas orientadas indicam as possíveis transferências entre os reservatórios.

\subsection{2 $\quad 2^{\mathrm{a}}$ Classe de Exemplares}

As características dos dados são as mesmas descritas na $1^{\text {a }}$ classe de exemplares, exceto o custo de manter ligada cada bomba às $18 \mathrm{~h}, 19 \mathrm{~h}$ e $20 \mathrm{~h}$, que foi tomado como sendo de 120 unidades monetárias, valor este tomado com base 


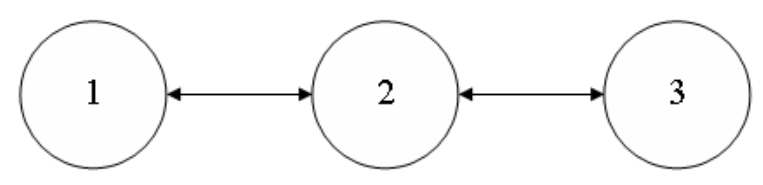

Figura 5.1: Sistema de abastecimento constituído por 3 reservatórios - $1^{\mathrm{a}}$ classe de exemplares.

na tarifa horo-sazonal verde (veja seção 3.2.1).

\subsection{3 $\quad 3^{\mathrm{a}}$ Classe de Exemplares}

Para estes exemplares consideramos 30 reservatórios, com volumes mínimos de $270 \mathrm{~m}^{3}$ para todos os reservatórios e volumes máximos de $2000 \mathrm{~m}^{3}$ para os reservatórios $6,15,22$ e 28 , e de $1000 \mathrm{~m}^{3}$ para os demais reservatórios. Os volumes iniciais dos reservatórios foram tomados como sendo de $500 \mathrm{~m}^{3}$.

A cada reservatório está associado um poço e uma bomba de captação. A vazão das bombas é de $300 \mathrm{~m}^{3}$ por hora. O custo de manter ligada cada bomba durante cada um dos períodos é igual a 30 unidades monetárias, exceto às $18 \mathrm{~h}, 19 \mathrm{~h}$ e $20 \mathrm{~h}$, quando o custo é de 60 unidades monetárias (estes valores foram tomados com base na tarifa horo-sazonal azul). O custo de acionar cada bomba foi arbitrado igual a 1 unidade monetária, em todos os períodos. As demandas foram geradas do mesmo modo que na $1^{\mathrm{a}}$ classe de exemplares.

O grafo apresentado na Figura 5.2 representa este sistema de abastecimento, as arestas orientadas indicam as possíveis transferências entre os reservatórios. Para todas as possíveis transferências foi considerado um custo de 3 unidades monetárias por período e vazão de $60 \mathrm{~m}^{3}$ por hora.

As próximas classes de exemplares são baseadas em informações sobre o sistema de abastecimento de São Carlos, fornecidas por funcionários do SAAE-São Carlos. Nesse sistema de abastecimento há vários reservatórios e conjuntos de reservatórios em que não há interligação com os demais reservatórios do sistema e, portanto, podem ser analisados independentemente dos demais reservatórios. As próximas três classes de exemplares juntas representam quase todo o sistema de abastecimento de São Carlos, totalizando 21 reservatórios. 


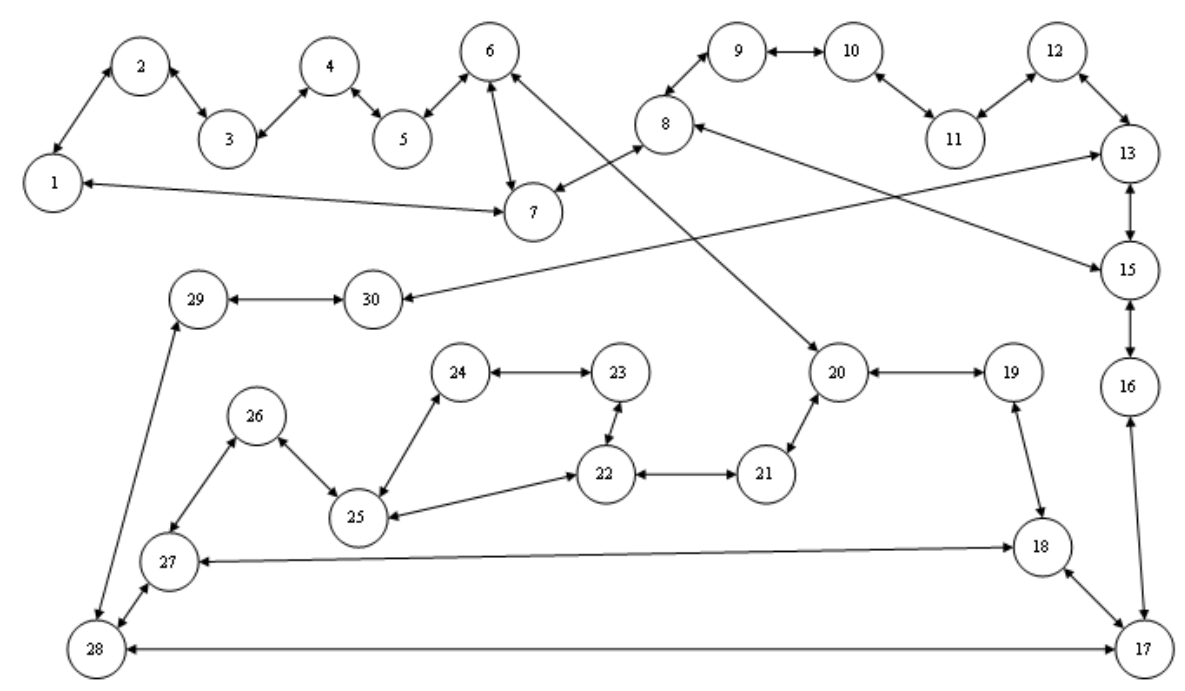

Figura 5.2: Sistema de abastecimento constituído por 30 reservatórios - $3^{\text {a }}$ classe de exemplares.

\subsection{4 $\quad 4^{\mathrm{a}}$ Classe de Exemplares}

Os dados foram baseados em 4 reservatórios da cidade de São Carlos. Os volumes mínimos e máximos de cada reservatório são apresentados na Tabela 5.2.

\begin{tabular}{|c|cccr|}
\hline Volume & \multicolumn{4}{|c|}{ Reservatórios } \\
& 1 & 2 & 3 & 4 \\
\hline Mínimo & $60 m^{3}$ & $225 m^{3}$ & $32 m^{3}$ & $780 m^{3}$ \\
\hline Máximo & $200 m^{3}$ & $750 m^{3}$ & $106 m^{3}$ & $2600 m^{3}$ \\
\hline
\end{tabular}

Tabela 5.2: Volumes mínimos e máximos dos reservatórios - $4^{\mathrm{a}}$ classe de exemplares.

Os reservatórios 1, 2 e 3 estão associados a três poços distintos e o reservatório 4 à Estação de Tratamento de Água e cada um destes está associado a uma bomba de captação. A vazão de cada bomba é apresentada na Tabela 5.3.

\begin{tabular}{|l|cccc|}
\hline & \multicolumn{4}{|c|}{ Bomba } \\
& 1 & 2 & 3 & 4 \\
\hline Vazão $\left(m^{3} / h\right)$ & 70 & 120 & 107 & 750 \\
\hline
\end{tabular}

Tabela 5.3: Vazão das bombas de captação - $4^{\mathrm{a}}$ classe de exemplares. 
Os custos de manter ligada cada bomba são diferenciados, pois o consumo de energia destas não é igual e são gerados adotando a tarifa horo-sazonal azul.

As demandas foram geradas uniformemente distribuídas em intervalos que representam as estimativas máximas e mínimas (para cada reservatório) em cada faixa horária, estas estimativas foram determinadas com base em Toledo et al. (2006).

Na Figura 5.3 representamos este sistema de abastecimento, as arestas orientadas representam as possíveis transferências entre os reservatórios. A transferência do reservatório 1 para o reservatório 2 ocorre por gravidade e praticamente não há custo, o mesmo ocorre do reservatório 3 para o reservatório 4 . Para as demais transferências há custo, as vazões e estes custos são diferenciados para cada possível transferência.

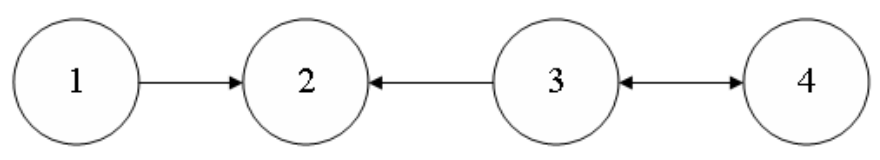

Figura 5.3: Sistema de abastecimento constituído por 4 reservatórios - $4^{\mathrm{a}}$ classe de exemplares.

\subsection{5 $\quad 5^{\text {a }}$ Classe de Exemplares}

Os dados foram baseados em 8 reservatórios da cidade de São Carlos. Os volumes mínimos e máximos dos reservatórios são apresentados na Tabela 5.4.

\begin{tabular}{|c|cccccccr|}
\hline Volume & \multicolumn{7}{|c|}{ Reservatórios } \\
& 1 & 2 & 3 & 4 & 5 & 6 & 7 & 8 \\
\hline Mínimo & $645 m^{3}$ & $660 m^{3}$ & $750 m^{3}$ & $60 m^{3}$ & $1140 m^{3}$ & $400 m^{3}$ & $1500 m^{3}$ & $270 m^{3}$ \\
\hline Máximo & $2150 m^{3}$ & $2200 m^{3}$ & $2500 m^{3}$ & $200 m^{3}$ & $3800 m^{3}$ & $2200 m^{3}$ & $5000 m^{3}$ & $900 m^{3}$ \\
\hline
\end{tabular}

Tabela 5.4: Volumes mínimos e máximos dos reservatórios - $5^{\mathrm{a}}$ classe de exemplares.

Os reservatórios 5 e 7 estão associados a ETA, e os demais reservatórios a poços distintos. A vazão de cada bomba é apresentada na Tabela 5.5.

Os custos de manter ligada cada bomba são diferenciados, e são gerados adotando a tarifa horo-sazonal azul.

As demandas foram geradas uniformemente distribuídas em intervalos que representam as estimativas máximas e mínimas (para cada reservatório) em cada 


\begin{tabular}{|c|cccccccc|}
\hline & \multicolumn{8}{|c|}{ Bomba } \\
& 1 & 2 & 3 & 4 & 5 & 6 & 7 & 8 \\
\hline Vazão $\left(m^{3} / h\right)$ & 215 & 298 & 282 & 90 & 750 & 86 & 300 & 122 \\
\hline
\end{tabular}

Tabela 5.5: Vazão das bombas de captação - $5^{\mathrm{a}}$ classe de exemplares.

faixa horária, estas estimativas foram determinadas com base em Toledo et al. (2006).

$\mathrm{Na}$ Figura 5.4 representamos este sistema de abastecimento, as arestas orientadas representam as possíveis transferências entre os reservatórios. As transferências do reservatório 2 para o reservatório 1 , do reservatório 4 para o 3, do reservatório 6 para o 7 e do reservatório 7 para 8 ocorrem por gravidade. Para as demais transferências há custo, as vazões e estes custos são diferenciados para cada possível transferência.

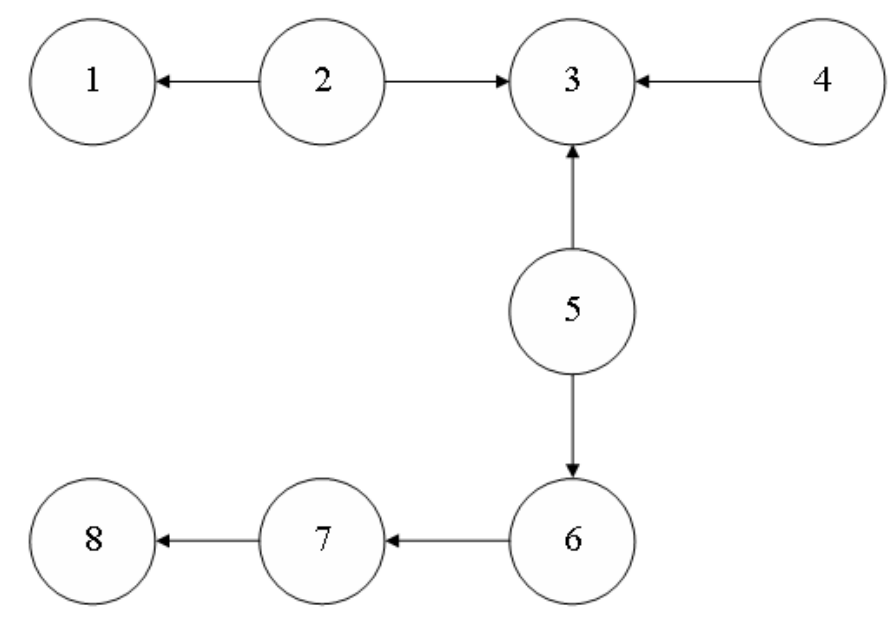

Figura 5.4: Sistema de abastecimento constituído por 8 reservatórios - $5^{\mathrm{a}}$ classe de exemplares.

\subsection{6 $\quad 6^{\mathrm{a}}$ Classe de Exemplares}

Os dados foram baseados em 9 reservatórios da cidade de São Carlos. Os volumes mínimos e máximos de cada reservatório são apresentados na Tabela 5.6.

O reservatório 3 está associado a ETA e os demais reservatórios a poços distintos. A vazão de cada bomba é apresentada na Tabela 5.7.

Os custos de manter ligada cada bomba são diferenciados, e são gerados adotando a tarifa horo-sazonal azul. 


\begin{tabular}{|c|ccccccccc|}
\hline Volume & \multicolumn{8}{|c|}{ Reservatórios } \\
& 1 & 2 & 3 & 4 & 5 & 6 & 7 & 8 & 9 \\
\hline Mínimo & $60 m^{3}$ & $60 m^{3}$ & $120 m^{3}$ & $30 m^{3}$ & $300 m^{3}$ & $30 m^{3}$ & $150 m^{3}$ & $9 m^{3}$ & $744 m^{3}$ \\
\hline Máximo & $200 m^{3}$ & $200 m^{3}$ & $400 m^{3}$ & $100 m^{3}$ & $1000 m^{3}$ & $100 m^{3}$ & $500 m^{3}$ & $30 m^{3}$ & $2480 m^{3}$ \\
\hline
\end{tabular}

Tabela 5.6: Volumes mínimos e máximos dos reservatórios - $6^{\mathrm{a}}$ classe de exemplares.

\begin{tabular}{|c|ccccccccc|}
\hline & \multicolumn{10}{|c|}{ Bomba } \\
& 1 & 2 & 3 & 4 & 5 & 6 & 7 & 8 & 9 \\
\hline Vazão $\left(m^{3} / h\right)$ & 100 & 22 & 30 & 48 & 100 & 83 & 88 & 35 & 328 \\
\hline
\end{tabular}

Tabela 5.7: Vazão das bombas de captação - $6^{\mathrm{a}}$ classe de exemplares.

As demandas foram geradas uniformemente distribuídas em intervalos que representam as estimativas máximas e mínimas (para cada reservatório) em cada faixa horária, com base em Toledo et al. (2006).

Na Figura 5.5 representamos este sistema de abastecimento, a única possível transferência é do reservatório 1 para o reservatório 2 e ocorre por gravidade.
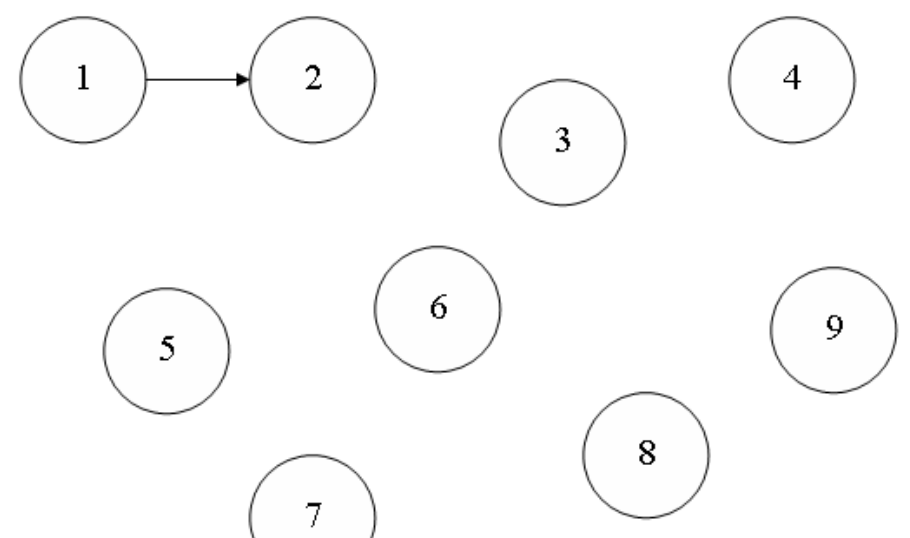

7

Figura 5.5: Sistema de abastecimento constituído por 9 reservatórios - $6^{\mathrm{a}}$ classe de exemplares. 


\subsection{Solução CPLEX $\chi$ Solução Heurística}

Para analisar a eficiência da heurística proposta, foram realizados testes computacionais nos quais as soluções obtidas pela heurística foram comparadas com as soluções obtidas pelo CPLEX. Em todos os testes o pacote CPLEX 7.5 foi executado com sua configuração padrão com tempo limite de 600 segundos.

Todos os testes foram realizados em um computador AMD Athlon(TM)XP $1700+, 1,11 \mathrm{GHz}, 480 \mathrm{MB}$ RAM.

\subsection{1 $\quad 1^{\mathrm{a}}$ Etapa de Testes}

Os dados foram gerados conforme descrito na $1^{\mathrm{a}}$ classe de exemplares, supondo não haver perdas de água para cada reservatório $\left(\theta_{j t}=0\right.$ para $j=1,2,3$ e $t=$ $1,2,3, \ldots, 48)$. Foram testados 5 exemplares.

A Tabela 5.8 compara os gaps obtidos pelo pacote CPLEX $7.5 \mathrm{com}$ os gaps obtidos pela heurística (o gap foi calculado pela diferença entre o valor da função objetivo da solução obtida e da solução do problema relaxado linearmente, dividida pelo valor da função objetivo da solução da relaxação linear). O tempo de solução do pacote foi de 600 segundos enquanto a heurística apresenta a solução instantaneamente.

\begin{tabular}{|l|r|r|}
\hline & GAP CPLEX & GAP Heurística \\
\hline Exemplo 1 & $0,39 \%$ & $0,51 \%$ \\
\hline Exemplo 2 & $0,27 \%$ & $0,95 \%$ \\
\hline Exemplo 3 & $0,34 \%$ & $0,61 \%$ \\
\hline Exemplo 4 & $0,16 \%$ & $0,62 \%$ \\
\hline Exemplo 5 & $0,32 \%$ & $0,60 \%$ \\
\hline
\end{tabular}

Tabela 5.8: Gaps obtidos pelo CPLEX e pela heurística - $1^{\mathrm{a}}$ etapa de testes.

Tanto as soluções obtidas pelo CPLEX 7.5 quanto as soluções obtidas pela heurística seguem um padrão de comportamento: no início do horário de ponta os reservatórios apresentam estoque de água, estão no seu nível máximo ou com estoque de água o suficiente para atender a demanda até o final do horizonte de planejamento. Além disso, em ambas as soluções, na maioria das vezes em que a bomba é acionada, esta é mantida ligada até que o nível máximo do reservatório seja atingido. Os gráficos apresentados nas Figuras 5.6, 5.7, 5.8, 5.9, 5.10 e 5.11 comparam as soluções obtidas pelo CPLEX e pela heurística para um dos exemplares. 


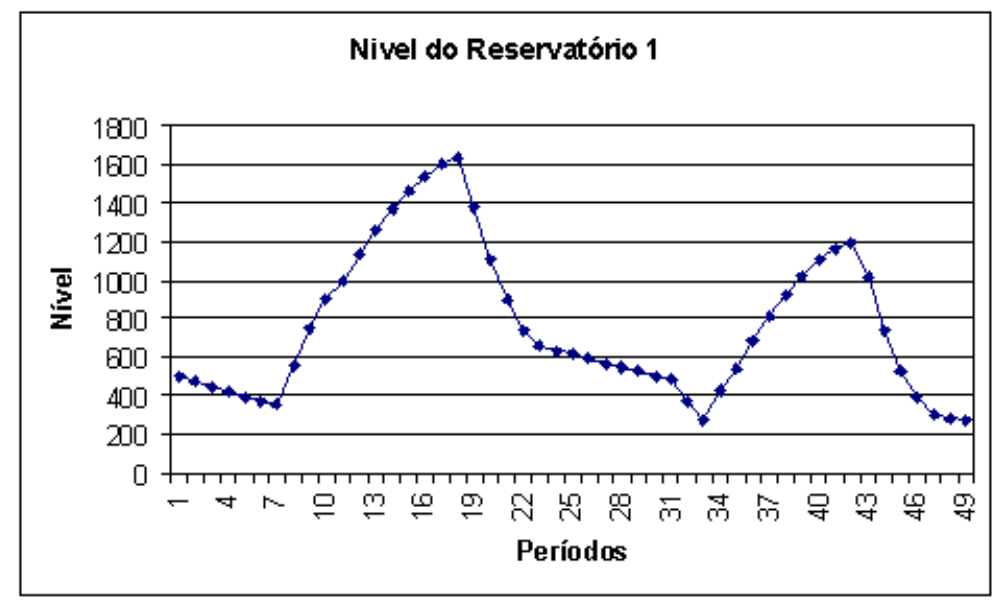

Figura 5.6: Gráfico do Reservatório 1 para a solução obtida pelo CPLEX - sem perdas de água.

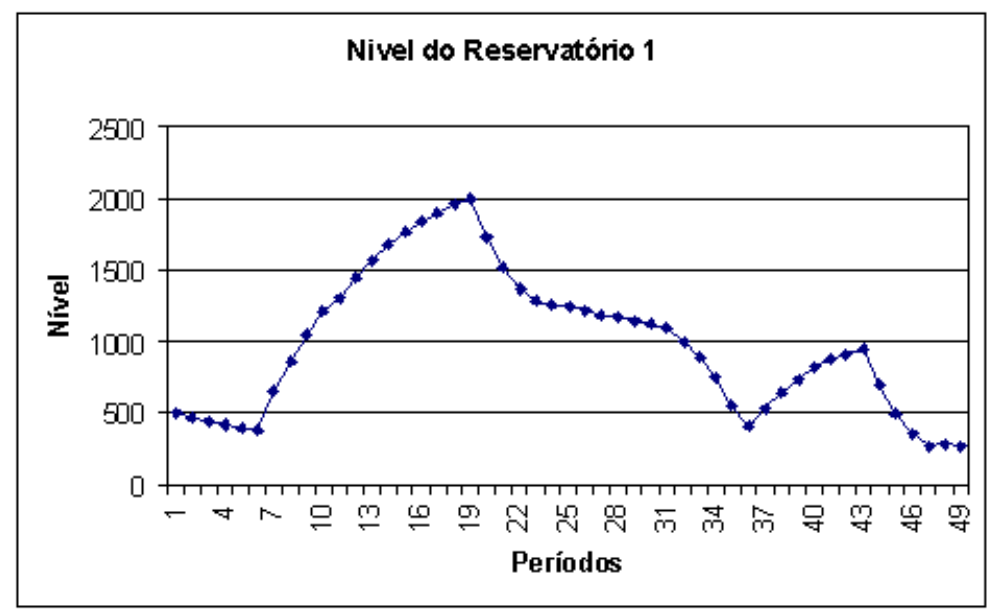

Figura 5.7: Gráfico do Reservatório 1 para a solução obtida pela heurística - sem perdas de água.

Nos exemplares testados tanto as soluções obtidas pelo CPLEX quanto as soluções obtidas pela heurística são de boa qualidade. A desvantagem do pacote CPLEX é o tempo de execução que é muito grande quando comparado com a heurística. 


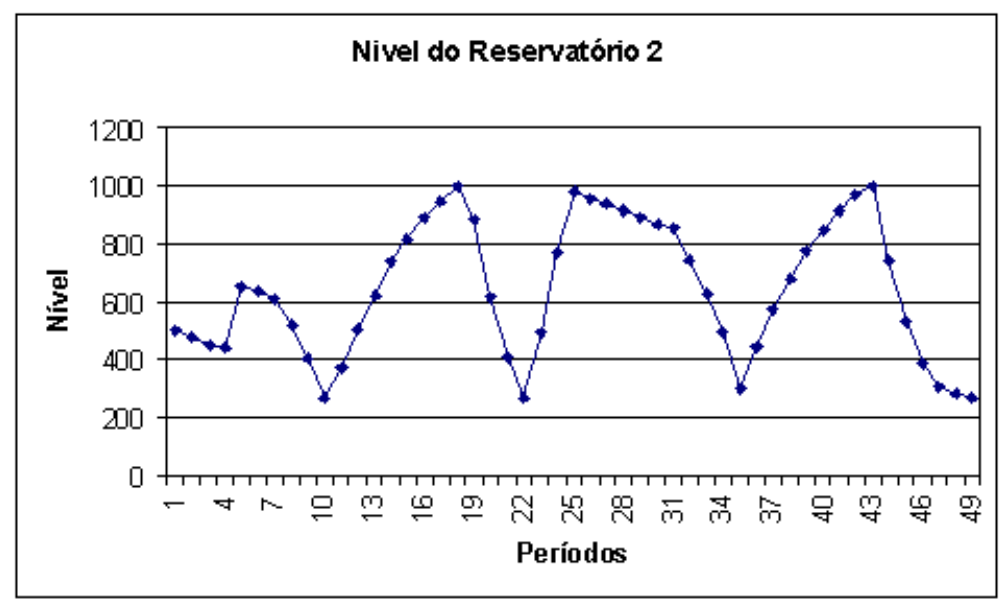

Figura 5.8: Gráfico do Reservatório 2 para a solução obtida pelo CPLEX - sem perdas de água.

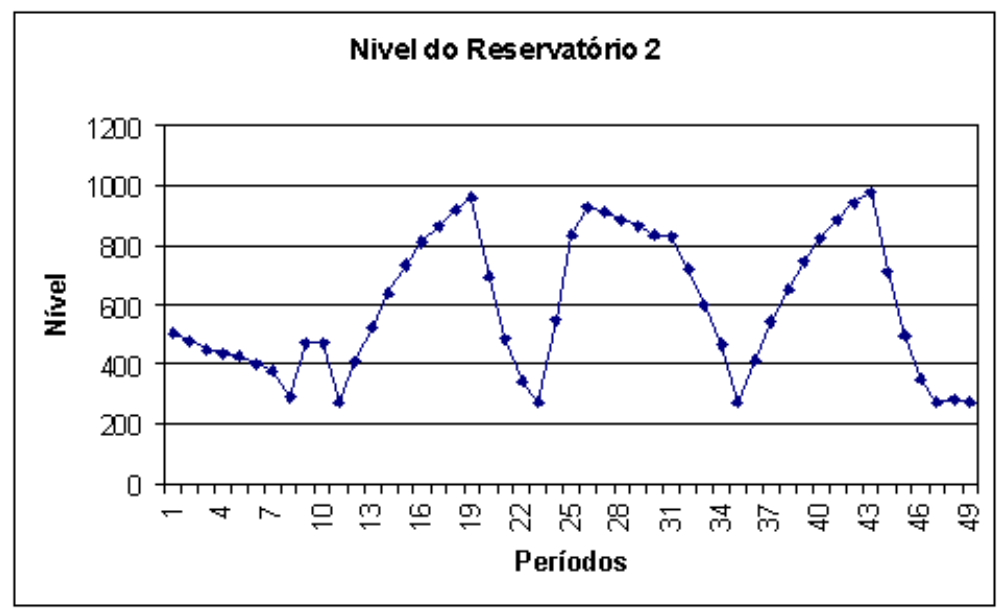

Figura 5.9: Gráfico do Reservatório 2 para a solução obtida pela heurística - sem perdas de água.

\subsection{2 $\quad 2^{\text {a }}$ Etapa de Testes}

Os dados foram gerados conforme descrito na $1^{\mathrm{a}}$ classe de exemplares, para perdas de água da ordem de $10 \%$ para cada reservatório. Foram testados 5 exemplares.

A Tabela 5.9 compara os gaps obtidos pelo pacote CPLEX 7.5 com os gaps obtidos pela heurística. O tempo de solução do pacote foi de 600 segundos 


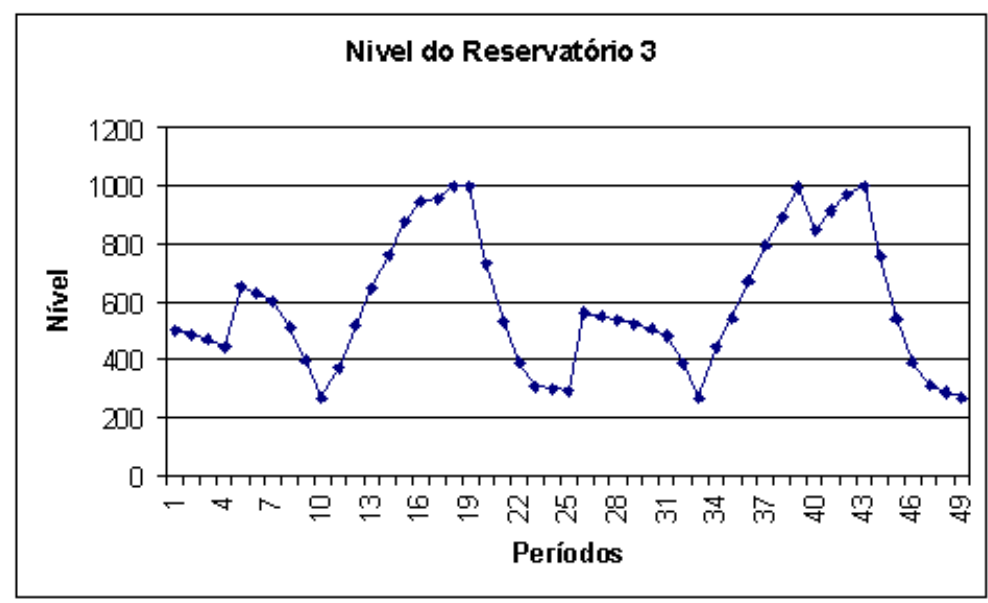

Figura 5.10: Gráfico do Reservatório 3 para a solução obtida pelo CPLEX - sem perdas de água.

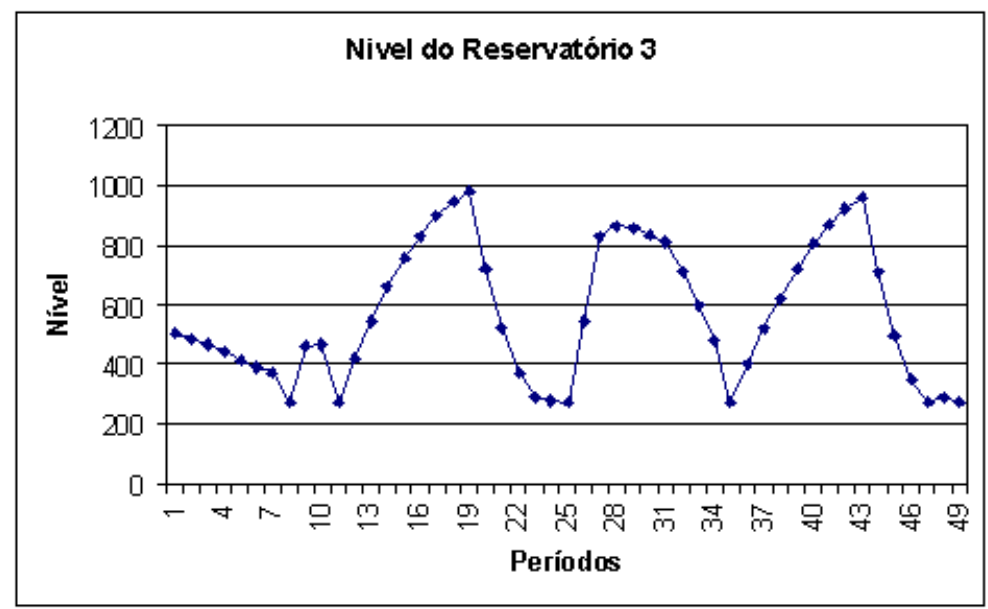

Figura 5.11: Gráfico do Reservatório 3 para a solução obtida pela heurística - sem perdas de água.

enquanto a heurística apresenta a solução instantaneamente.

Tanto nas soluções obtidas pelo CPLEX 7.5 quanto nas soluções obtidas pela heurística no início do horário de ponta os reservatórios apresentam estoque de água, mas não estão no seu nível máximo. Isto ocorre pois, devido às perdas de água, nem sempre é conveniente armazenar água. Nas soluções obtidas pelo 


\begin{tabular}{|c|c|c|}
\hline & GAP CPLEX & GAP Heurística \\
\hline Exemplo1 & $0,87 \%$ & $1,2 \%$ \\
\hline Exemplo2 & $0,90 \%$ & $1,2 \%$ \\
\hline Exemplo3 & $0,78 \%$ & $1,1 \%$ \\
\hline Exemplo4 & $0,81 \%$ & $1,1 \%$ \\
\hline Exemplo5 & $0,76 \%$ & $1,1 \%$ \\
\hline
\end{tabular}

Tabela 5.9: Gaps obtidos pelo CPLEX e pela heurística - $2^{\mathrm{a}}$ etapa de testes.

CPLEX os reservatórios armazenam água em alguns períodos fora do horário de ponta e, nestes horários, os níveis dos reservatórios se mantém próximos do nível mínimo. Nas soluções obtidas pela heurística, nos horários fora de ponta os reservatórios se mantém com seus níveis mínimos.

Os gráficos apresentados nas Figuras 5.12, 5.13, 5.14, 5.15, 5.16 e 5.17 comparam as soluções obtidas pelo CPLEX e pela heurística para um dos exemplares resolvidos.

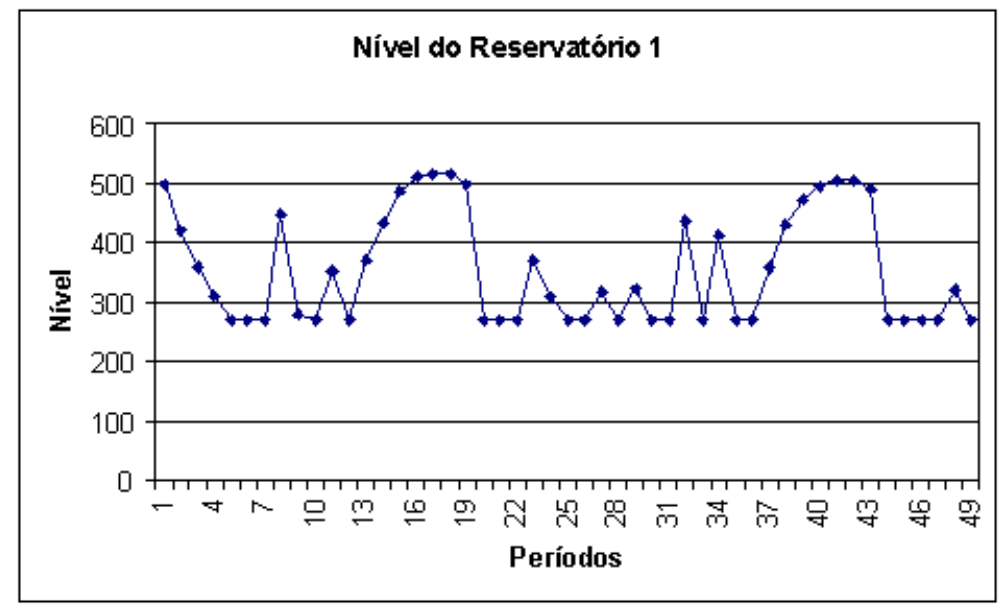

Figura 5.12: Gráfico do Reservatório 1 para a solução obtida pelo CPLEX - perdas de água de $10 \%$.

Novamente, nos exemplares testados, tanto as soluções obtidas pelo CPLEX quanto as soluções obtidas pela heurística são de boa qualidade. A desvantagem do pacote CPLEX é o tempo de execução que é muito grande quando comparado com a heurística. 


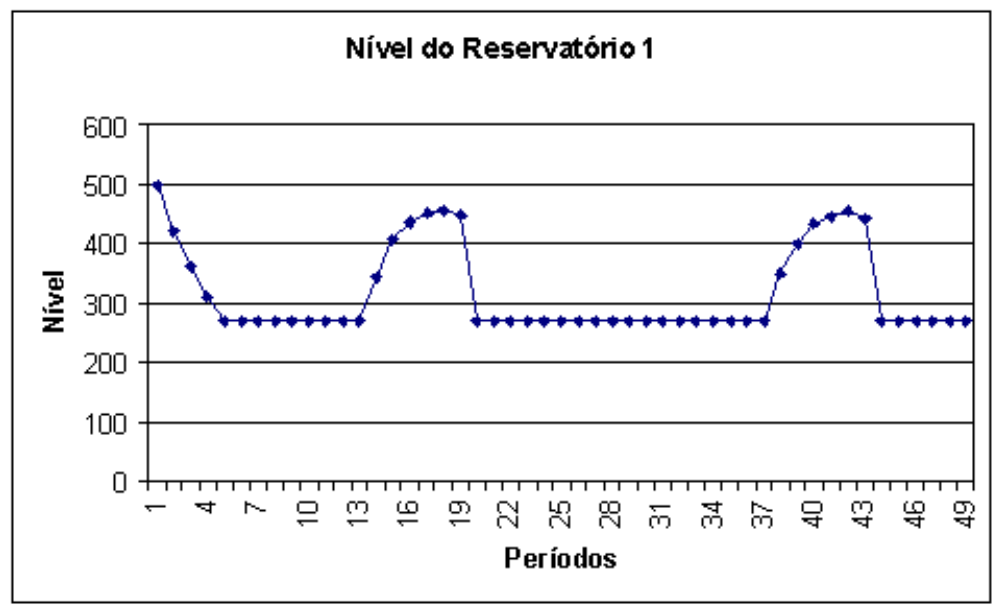

Figura 5.13: Gráfico do Reservatório 1 para a solução obtida pela heurística perdas de água de $10 \%$.

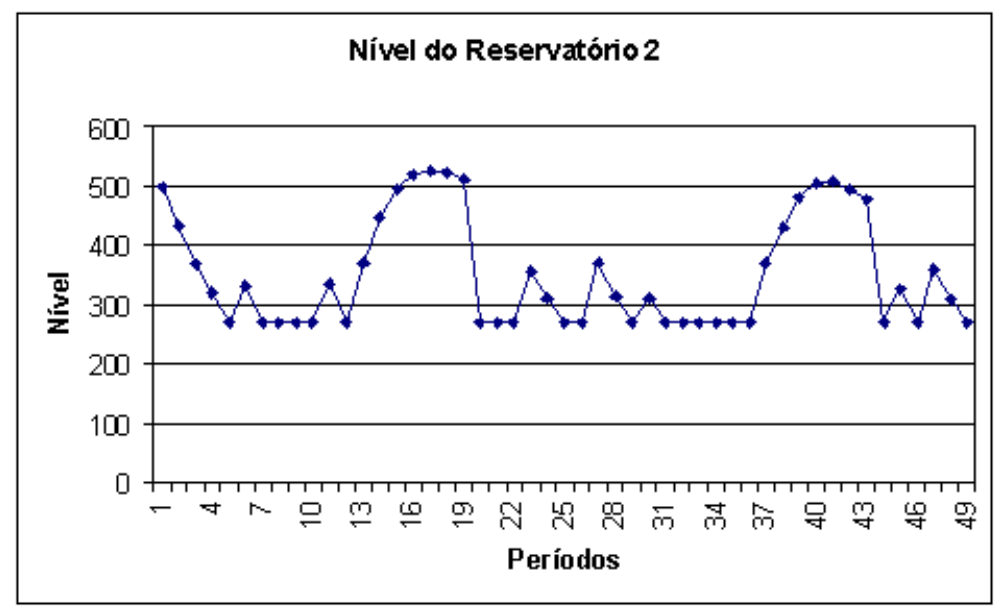

Figura 5.14: Gráfico do Reservatório 2 para a solução obtida pelo CPLEX - perdas de água de $10 \%$.

\subsection{3 $\quad 3^{\text {a }}$ Etapa de Testes}

Os dados foram gerados conforme descrito na $1^{\mathrm{a}}$ classe de exemplares, para perdas de água da ordem de $20 \%$ para cada reservatório. Foram testados 5 exemplares.

A Tabela 5.10 compara os gaps obtidos pelo pacote CPLEX 7.5 com os gaps obtidos pela heurística. As soluções obtidas pela heurística apresentam gap menor 


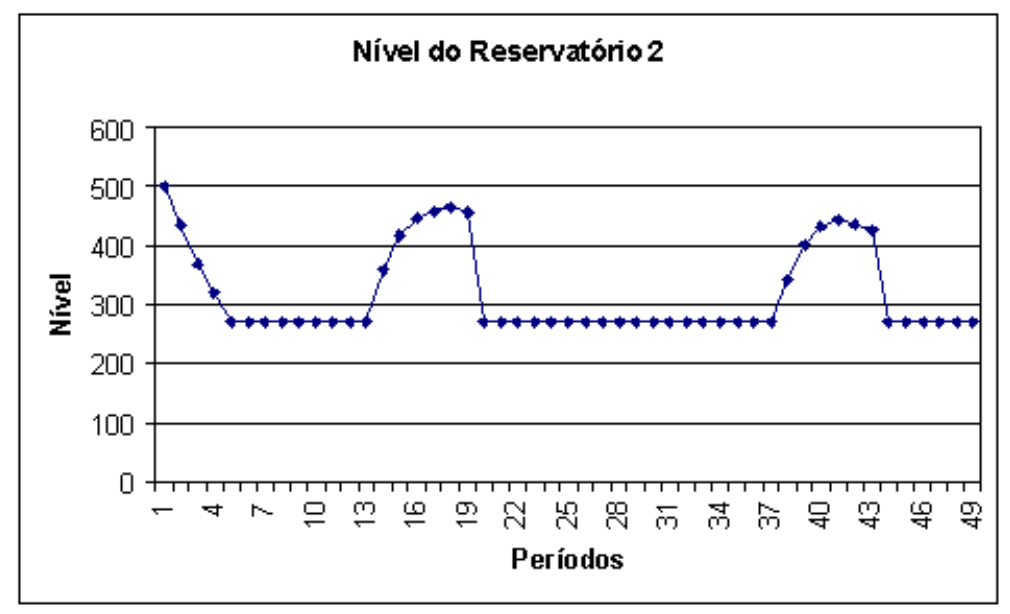

Figura 5.15: Gráfico do Reservatório 2 para a solução obtida pela heurística perdas de água de $10 \%$.

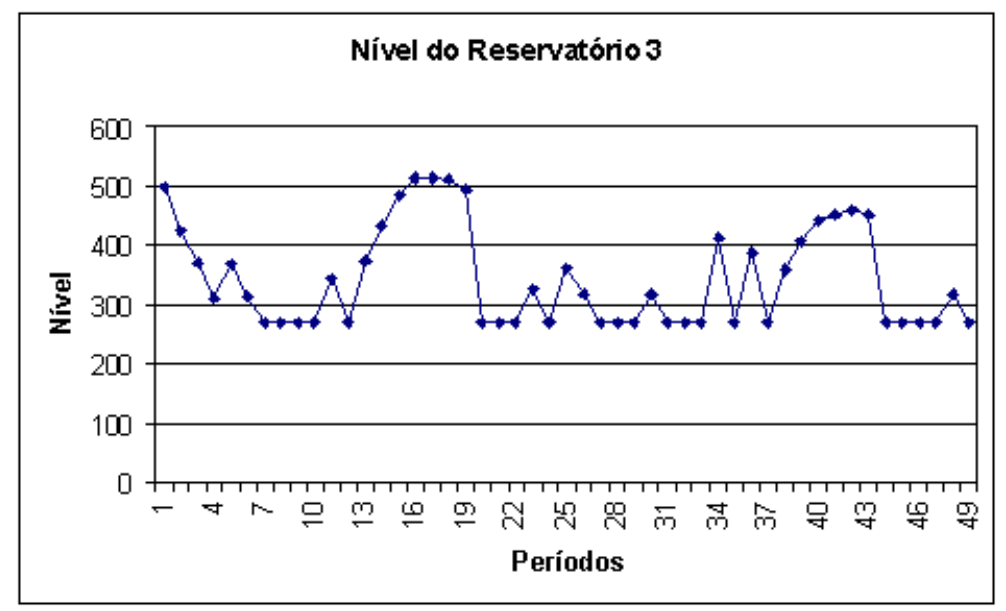

Figura 5.16: Gráfico do Reservatório 3 para a solução obtida pelo CPLEX - perdas de água de $10 \%$.

do que as soluções obtidas pelo pacote. O tempo de solução do CPLEX foi de 600 segundos enquanto a heurística apresenta a solução instantaneamente.

Tanto as soluções obtidas pelo CPLEX 7.5 quanto as soluções obtidas pela heurística seguem um padrão de comportamento: no início do horário de ponta os reservatórios apresentam estoque de água, mas não estão no seu nível máximo. Isto 


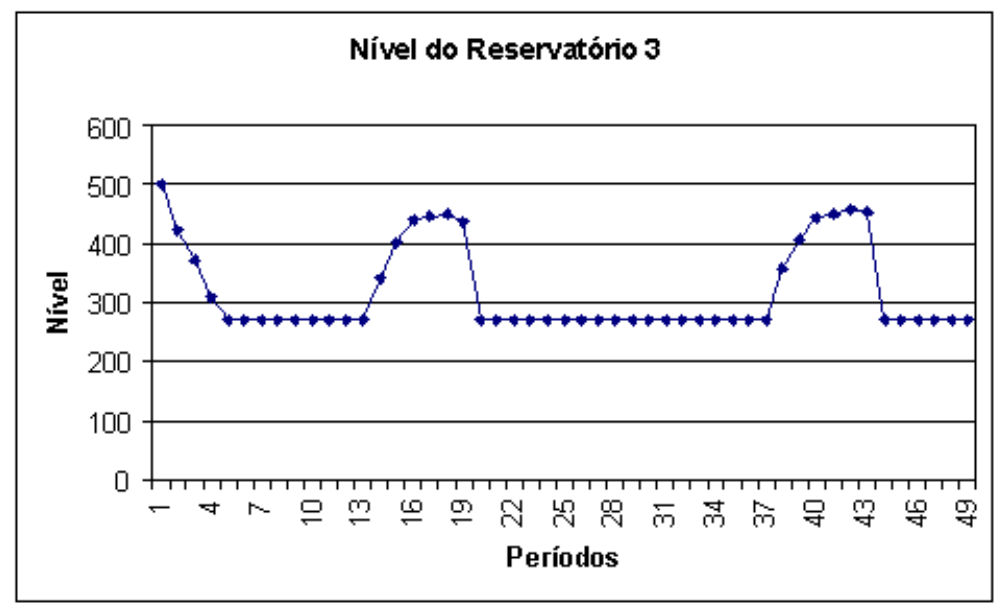

Figura 5.17: Gráfico do Reservatório 3 para a solução obtida pela heurística perdas de água de $10 \%$.

\begin{tabular}{|l|c|c|}
\hline & GAP CPLEX & GAP Heurística \\
\hline Exemplo 1 & $0,68 \%$ & $0,50 \%$ \\
\hline Exemplo 2 & $0,83 \%$ & $0,50 \%$ \\
\hline Exemplo 3 & $0,75 \%$ & $0,49 \%$ \\
\hline Exemplo 4 & $0,61 \%$ & $0,44 \%$ \\
\hline Exemplo 5 & $0,82 \%$ & $0,54 \%$ \\
\hline
\end{tabular}

Tabela 5.10: Gaps obtidos pelo CPLEX e pela heurística - $3^{\mathrm{a}}$ etapa de testes.

ocorre pois, devido às perdas de água, nem sempre é conveniente armazenar água. Os gráficos apresentados nas Figuras 5.18 e 5.19 comparam as soluções obtidas pelo CPLEX e pela heurística. Apresentamos apenas os gráficos no reservatório 1, pois os demais reservatórios apresentam comportamento similiar embora as suas capacidads sejam diferentes, devido às perdas de água, mesmo nos períodos antecedentes aos períodos de ponta, os níveis dos reservatórios se mantém próximos do nível mínimo permitido.

\subsection{4 $\quad 4^{\mathrm{a}}$ Etapa de Testes}

Os dados foram gerados conforme descrito na $4^{\mathrm{a}}$ classe de exemplares, para perdas de água da ordem de $10 \%$ para cada reservatório. Foram testados 5 exemplares.

A Tabela 5.11 compara os gaps obtidos pelo pacote CPLEX 7.5 com os gaps obtidos pela heurística. O tempo de solução do pacote foi de 600 segundos 


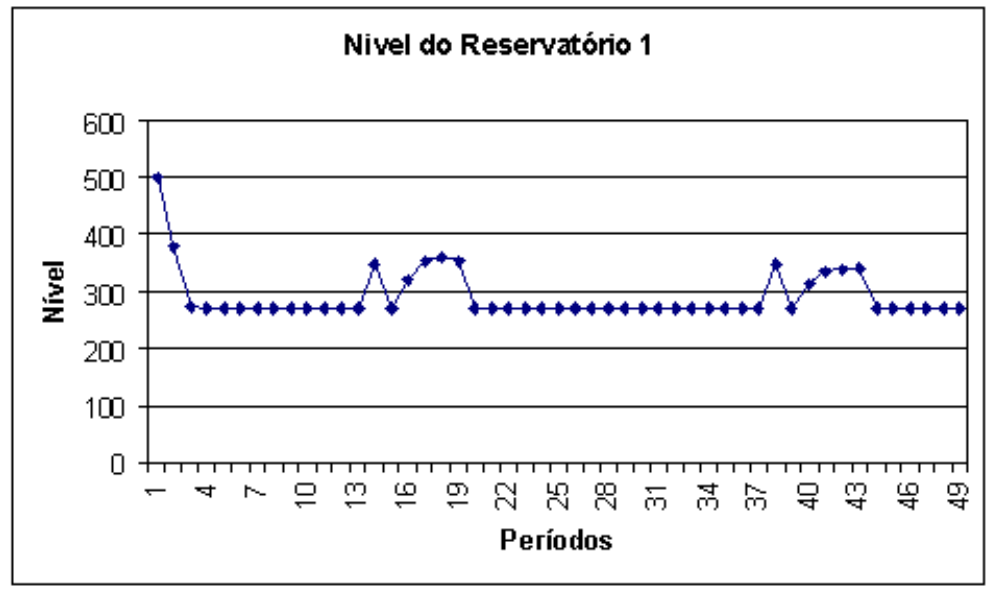

Figura 5.18: Gráfico do Reservatório 1 para a solução obtida pelo CPLEX - perdas de água de $20 \%$.

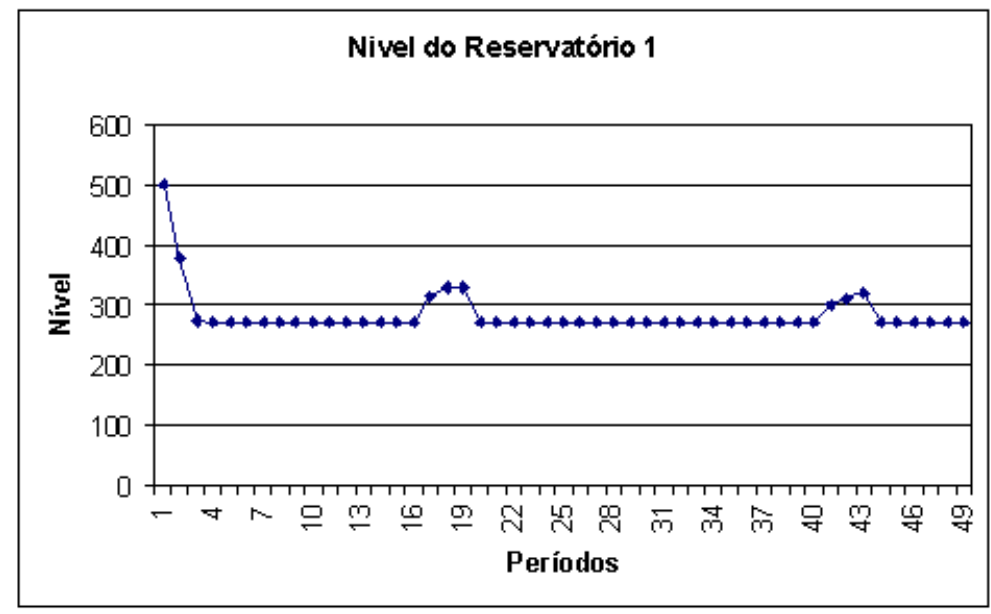

Figura 5.19: Gráfico do Reservatório 1 para a solução obtida pela heurística perdas de água de $20 \%$.

enquanto a heurística apresenta a solução instantaneamente. 


\begin{tabular}{|l|r|r|}
\hline & GAP CPLEX & GAP Heurística \\
\hline Exemplo 1 & $0,79 \%$ & $2,22 \%$ \\
\hline Exemplo 2 & $0,63 \%$ & $2,33 \%$ \\
\hline Exemplo 3 & $0,91 \%$ & $2,29 \%$ \\
\hline Exemplo 4 & $0,52 \%$ & $1,45 \%$ \\
\hline Exemplo 5 & $0,82 \%$ & $1,98 \%$ \\
\hline
\end{tabular}

Tabela 5.11: Gaps obtidos pelo CPLEX e pela heurística - $4^{\mathrm{a}}$ etapa de testes.

\subsection{5 $\quad 5^{\mathrm{a}}$ Etapa de Testes}

Os dados foram gerados conforme descrito na $5^{\mathrm{a}}$ classe de exemplares, para perdas de água da ordem de $10 \%$ para cada reservatório. Foram testados 5 exemplares.

A Tabela 5.12 compara os gaps obtidos pelo pacote CPLEX 7.5 com os gaps obtidos pela heurística. O tempo de solução do pacote foi de 600 segundos enquanto a heurística apresenta a solução instantaneamente.

\begin{tabular}{|l|r|r|}
\hline & GAP CPLEX & GAP Heurística \\
\hline Exemplo 1 & $1,24 \%$ & $3,30 \%$ \\
\hline Exemplo 2 & $1,26 \%$ & $3,34 \%$ \\
\hline Exemplo 3 & $1,15 \%$ & $3,24 \%$ \\
\hline Exemplo 4 & $1,15 \%$ & $3,23 \%$ \\
\hline Exemplo 5 & $1,28 \%$ & $3,23 \%$ \\
\hline
\end{tabular}

Tabela 5.12: Gaps obtidos pelo CPLEX e pela heurística - $5^{\mathrm{a}}$ etapa de testes.

\subsection{6 $\quad 6^{\mathrm{a}}$ Etapa de Testes}

Os dados foram gerados conforme descrito na $6^{\mathrm{a}}$ classe de exemplares, para perdas de água da ordem de $10 \%$ para cada reservatório. Foram testados 5 exemplares.

A Tabela 5.13 compara os gaps obtidos pelo pacote CPLEX 7.5 com os gaps obtidos pela heurística. O tempo de solução do pacote foi de 600 segundos enquanto a heurística apresenta a solução instantaneamente. 


\begin{tabular}{|l|r|r|}
\hline & GAP CPLEX & GAP Heurística \\
\hline Exemplo 1 & $0,31 \%$ & $2,01 \%$ \\
\hline Exemplo 2 & $0,32 \%$ & $2,06 \%$ \\
\hline Exemplo 3 & $0,35 \%$ & $1,17 \%$ \\
\hline Exemplo 4 & $0,43 \%$ & $2,46 \%$ \\
\hline Exemplo 5 & $0,27 \%$ & $2,01 \%$ \\
\hline
\end{tabular}

Tabela 5.13: Gaps obtidos pelo CPLEX e pela heurística - $6^{\mathrm{a}}$ etapa de testes.

\subsection{7 $\quad 7^{\mathrm{a}}$ Etapa de Testes}

Os dados foram gerados conforme descrito na $3^{\mathrm{a}}$ classe de exemplares, para perdas de água da ordem de $10 \%$ para cada reservatório. Foram testados 5 exemplares.

A Tabela 5.14 compara os gaps obtidos pelo pacote CPLEX 7.5 com os gaps obtidos pela heurística. O tempo de solução do pacote foi de 600 segundos enquanto a heurística apresenta a solução instantaneamente.

\begin{tabular}{|l|r|r|}
\hline & GAP CPLEX & GAP Heurística \\
\hline Exemplo 1 & $2,67 \%$ & $2,66 \%$ \\
\hline Exemplo 2 & $2,58 \%$ & $2,64 \%$ \\
\hline Exemplo 3 & $2,62 \%$ & $2,67 \%$ \\
\hline Exemplo 4 & $2,61 \%$ & $2,64 \%$ \\
\hline Exemplo 5 & $2,60 \%$ & $2,65 \%$ \\
\hline
\end{tabular}

Tabela 5.14: Gaps obtidos pelo CPLEX e pela heurística - $7^{\mathrm{a}}$ etapa de testes.

\subsection{8 $\quad 8^{\mathrm{a}}$ Etapa de Testes}

Os dados foram gerados conforme descrito na $2^{\mathrm{a}}$ classe de exemplares (nesta classe de exemplares usamos o sistema tarifário horo-sazonal verde) supondo não haver perdas de água. Foram testados 5 exemplares.

A Tabela 5.15 compara os gaps obtidos pelo pacote CPLEX 7.5 com os gaps obtidos pela heurística. O tempo de solução do pacote foi de 600 segundos enquanto a heurística apresenta a solução instantaneamente. 


\begin{tabular}{|l|r|r|}
\hline & GAP CPLEX & GAP Heurística \\
\hline Exemplo 1 & $0,19 \%$ & $1,19 \%$ \\
\hline Exemplo 2 & $0,30 \%$ & $0,99 \%$ \\
\hline Exemplo 3 & $0,25 \%$ & $0,75 \%$ \\
\hline Exemplo 4 & $0,26 \%$ & $0,20 \%$ \\
\hline Exemplo 5 & $0,21 \%$ & $0,50 \%$ \\
\hline
\end{tabular}

Tabela 5.15: Gaps obtidos pelo CPLEX e pela heurística - $8^{\mathrm{a}}$ etapa de testes.

\subsection{9 $\quad 9^{\mathrm{a}}$ Etapa de Testes}

Os dados foram gerados conforme descrito na $2^{\text {a }}$ classe de exemplares (nesta classe de exemplares usamos o sistema tarifário horo-sazonal verde), para perdas de água da ordem de $10 \%$ para cada reservatório . Foram testados 5 exemplares.

A Tabela 5.16 compara os gaps obtidos pelo pacote CPLEX 7.5 com os gaps obtidos pela heurística. O tempo de solução do pacote foi de 600 segundos enquanto a heurística apresenta a solução instantaneamente.

\begin{tabular}{|l|r|r|}
\hline & GAP CPLEX & GAP Heurística \\
\hline Exemplo 1 & $0,02 \%$ & $0,61 \%$ \\
\hline Exemplo 2 & $0,03 \%$ & $0,56 \%$ \\
\hline Exemplo 3 & $0,03 \%$ & $0,60 \%$ \\
\hline Exemplo 4 & $0,03 \%$ & $0,55 \%$ \\
\hline Exemplo 5 & $0,01 \%$ & $0,56 \%$ \\
\hline
\end{tabular}

Tabela 5.16: Gaps obtidos pelo CPLEX e pela heurística - $9^{\mathrm{a}}$ etapa de testes.

\subsubsection{0 $10^{\mathrm{a}}$ Etapa de Testes}

Os dados foram gerados conforme descrito na $2^{\mathrm{a}}$ classe de exemplares (nesta classe de exemplares usamos o sistema tarifário horo-sazonal verde) para perdas de água da ordem de 20\%. Foram testados 5 exemplares.

A Tabela 5.17 compara os gaps obtidos pelo pacote CPLEX 7.5 com os gaps obtidos pela heurística. O tempo de solução do pacote foi de 600 segundos enquanto a heurística apresenta a solução instantaneamente. 


\begin{tabular}{|l|r|r|}
\hline & GAP CPLEX & GAP Heurística \\
\hline Exemplo 1 & $0,10 \%$ & $0,22 \%$ \\
\hline Exemplo 2 & $0,13 \%$ & $0,24 \%$ \\
\hline Exemplo 3 & $0,19 \%$ & $0,25 \%$ \\
\hline Exemplo 4 & $0,14 \%$ & $0,27 \%$ \\
\hline Exemplo 5 & $0,14 \%$ & $0,22 \%$ \\
\hline
\end{tabular}

Tabela 5.17: Gaps obtidos pelo CPLEX e pela heurística - $10^{\mathrm{a}}$ etapa de testes.

\subsubsection{1 $11^{\mathrm{a}}$ Etapa de Testes}

Nesta etapa resolvemos um mesmo exemplar gerado conforme a $1^{\mathrm{a}}$ classe de exemplares, para diferentes perdas: sem perdas, perdas de $10 \%$ e perdas de $20 \%$ de água por hora. Os testes indicaram que os valores obtidos para a função objetivo dos problemas sem perdas de água são aproximadamente $40 \%$ menores do que os valores obtidos para a função objetivo dos problemas com perdas de água de $10 \%$. E os valores obtidos para a função objetivo dos problemas sem perdas de água são aproximadamente $70 \%$ menores do que os valores obtidos para a função objetivo dos problemas com perdas de água de $20 \%$.

Ou seja, a redução das perdas de água em um sistema de abastecimento proporcionam economias significativas de energia elétrica.

\subsubsection{2 $12^{\mathrm{a}}$ Etapa de Testes}

Nesta etapa resolvemos um mesmo exemplar gerado conforme a $1^{\mathrm{a}}$ classe de exemplares sem perdas de água, com e sem as ligações entre os reservatórios. Os testes indicaram que os valores obtidos para a função objetivo dos problemas com as ligações entre os reservatórios são cerca de 10\% menores do que os valores obtidos para a função objetivo dos problemas sem as ligações entre os reservatórios.

Ou seja, as ligações entre os reservatórios, possibilitando a transferência de água entre estes, podem resultar em economias nos gastos com energia elétrica em sistemas de abastecimento.

\subsubsection{3 $13^{\mathrm{a}}$ Etapa de Testes}

Nesta etapa resolvemos um mesmo exemplar gerado conforme a $1^{\mathrm{a}}$ classe de exemplares sem perdas de água, supondo a capacidade do reservatório 1 de $1000 \mathrm{~m}^{3}$ e de $2000 m^{3}$. Os testes indicaram que os valores obtidos para a função objetivo dos problemas com a capacidade do reservatório 1 de $2000 \mathrm{~m}^{3}$ são aproximadamente $20 \%$ menores do que os valores obtidos para a função objetivo dos problemas com a capacidade do reservatório 1 de $1000 \mathrm{~m}^{3}$. 
Ou seja, o aumento das capacidades dos reservatórios possibilitam redução dos gastos com energia elétrica em sistemas de abastecimento. 


\section{Capítulo 6}

\section{Conclusões e Perspectivas}

Nesta dissertação foi abordado um problema de planejamento de estoque de água em reservatórios (PPEAR) que consiste em operar um conjunto de bombas hidráulicas, as quais são usadas para captar água de poços ou ETA e armazenar em reservatórios para então atender uma população de uma cidade.

Um modelo de otimização linear inteiro foi revisado da literatura, cujas restrições garantem o abastecimento, níveis mínimos e máximos dos reservatórios e inclui a possibilidade de transferências de água entre reservatórios e perdas de água do sistema. A função objetivo, a ser minimizada, consiste do custo de energia elétrica da operação das bombas, o qual varia ao longo do dia.

A resolução do modelo pelo método de enumeração implícita, como implementado no pacote CPLEX, permitiu observar algumas características de uma solução de boa qualidade (baixo gap) e uma heurística foi proposta. Em essência, a heurística procura manter os reservatórios com estoque de água nos períodos que precedem aos horários de ponta (de alto custo de energia elétrica) e durante os horários de ponta (chamados períodos críticos), caso seja necessário, busca transferir água entre os reservatórios (caminhos de custos de transferência mínimos são determinados) e, em último caso, liga-se a bomba. Nos períodos em que as bombas são acionadas para armazenar água para os horários de ponta (chamados períodos pré-críticos) as perdas no sistema são consideradas e notou-se uma crescente dificuldade de operação com o aumento das perdas. Nos demais períodos (chamados não críticos), optou-se por manter os reservatórios em seus níveis mínimos e não fazer transferência. A heurística produz soluções de boa qualidade em tempo de execução muito pequeno, o que viabiliza seu uso prático.

Embora não tenha sido explorado nesta dissertação, deve-se ter em mente que os dados de demanda (aqui supostos determinados) são estocásticos. Assim, um planejamento de um horizonte de dois dias deve ser revisado periodicamente, mais acentuadamente nos horários de ponta, quando a demanda é maior. Ou seja, a estratégia de horizonte rolante deve ser utilizada. Portanto, para que a 
abordagem proposta nesta dissertação seja usada na prática, os níveis reais dos reservatórios (medidos por sensores em cada reservatório) devem ser comparados periodicamente com os níveis idealizados pelo modelo e, dependendo do erro observado, o modelo deve ser resolvido novamente com os dados atualizados, isto é, níveis iniciais e estado das bombas atualizados. Por esta razão um procedimento rápido é fundamental. Concomitantemente, um estudo mais acurado de previsão de demanda deve ser realizado.

Um outro uso do modelo, além da operação do sistema, é de projeto de expansão. Por exemplo, pode-se avaliar pela solução do modelo o impacto nos custos de energia elétrica pelo aumento da capacidade de alguns reservatórios, ou construção de novas ligações entre reservatórios, bem como ampliações das ligações existentes. Pode-se também avaliar em quanto tempo os preços de bombas hidráulicas mais eficientes são recuperados pela diminuição dos custos operacionais. 


\section{Apêndice A}

\section{Algoritmo de Floyd}

O algoritmo de Floyd encontra os caminhos mínimos entre todos os pares de nós de um grafo. Este algoritmo funciona somente se no grafo não existir circuitos com comprimentos negativos. O algoritmo de Floyd determina de maneira recursiva as distâncias mínimas entre os pares de nós de um grafo: na iteração $k$, é determinado o caminho mínimo entre dois nós quaisquer utilizando somente os $k$ primeiros nós. A seguir explicamos o algoritmo.

Considere um grafo constituído por $n$ nós e denote por $c(i, j)$ o valor associado a aresta que liga o nó i ao nó j. Seja $d^{k}(i, j)$ a menor distância entre os nós $i$ e $j$, dentre todos os caminhos que passam pelos $k$ primeiros nós. Seja $d^{0}(i, j)$ a menor distância de $i$ a $j$ não passando por nenhum nó, ou seja, $d^{0}(i, j)=c(i, j)$ se o arco $(i, j)$ existir, ou $d^{0}(i, j)=\infty$ caso contrário. Notemos que $d^{k}(i, j)=\infty$ significa que não há nenhum caminho entre os nós $i$ e $j$ que passe apenas pelos $k$ primeiros nós. Por definição, $d^{0}(i, i)=0$ para todo $i$. Como existem $n$ nós no grafo, $d^{n}(i, j)$ é a menor distância procurada, entre os nós $i$ e $j$.

O menor caminho de $i$ a $j$ que pode passar apenas pelos primeiros $k$ nós passa ou não pelo k-ésimo nó. Se não passa pelo k-ésimo nó, então a menor distância de $i$ a $j$ que pode passar pelos $k$ primeiros nós é igual à menor distância de $i$ a $j$ que pode passar pelos $k-1$ primeiros nós. Por outro lado, se o menor caminho passa pelo k-ésimo nó, então o caminho mínimo que passa pelo k-ésimo nó é composto do caminho mínimo de $i$ a $k$ que pode passar apenas pelos primeiros $k-1$ nós, com o caminho mínimo de $k$ a $j$ que pode passar pelos primeiros $k-1$ nós. Temos portanto,

$$
d^{k}(i, j)=\min \left(d^{k-1}(i, j), d^{k-1}(i, k)+d^{k-1}(k, j)\right) .
$$

Esta fórmula recursiva mostra que podemos determinar $d^{k}(i, j)$ a partir de $d^{k-1}(i, j), d^{k-1}(i, k)$ e $d^{k-1}(k, j)$. Como obtemos $d^{0}(i, j)$ para todos nós $i$ e $j$ do grafo, é possível calcular $d^{1}(i, j), d^{2}(i, j), d^{3}(i, j)$, e assim sucessivamente até $d^{n}(i, j)$ para todos os nós $i$ e $j$ do grafo. 
Para recuperar o caminho mínimo do nó $i$ ao nó $j$, basta armazenar durante os cálculos o penúltimo nó (o nó anterior ao nó $j$, denotado por $p(i, j)$ ) do caminho que fornece a menor distância. Isto é, na fórmula recursiva anterior, se $d^{k}(i, j)=d^{k-1}(i, k)+d^{k-1}(k, j)$, então $p(i, j)=p(k, j)$. Por exemplo, $p(5,2)=3$ significa que o caminho mínimo de 5 a 2 (ainda desconhecido) passa pelo nó 3 antes de chegar no nó 2 e $p(5,3)$ fornece o nó anterior a 3 , e assim por diante. Recuperando passo a passo os nós anteriores recupera-se o caminho mínimo.

\section{Algoritmo de Floyd}

\section{Dados:}

$G(N, E)$ : grafo com $n$ nós

$c(i, j)$ : comprimento do arco que liga o nó $i$ ao nó $j$

\section{Saída:}

$d(i, j)$ : menor distância do nó $i$ ao nó $j$

$p(i, j)$ : penúltimo nó intermediário no caminho mínimo do nó $i$ ao nó $j$

\section{Passo 1:}

$d^{0}(i, j)=c(i, j)$ se $(i, j) \in E$

$d^{0}(i, j)=\infty$ se $(i, j) \notin E, i \neq j$

$d^{0}(i, i)=0$ para $i=1,2,3, \ldots, n$

$p(i, j)=i$ para $i=1,2,3, \ldots, n$

\section{Passo 2:}

Para $\mathrm{k}=1,2, \ldots, \mathrm{n}$, faça:

$d^{k}(i, j)=\min \left(d^{k-1}(i, j), d^{k-1}(i, k)+d^{k-1}(k, j)\right)$.

e, se $d^{k}(i, j)=d^{k-1}(i, k)+d^{k-1}(k, j)$, então $p(i, j) \leftarrow p(k, j)$ 


\section{Referências Bibliográficas}

Almeida, R. (2001). Operação de Sistemas Urbanos de abastecimento de água com base em modelos de otimização não lineares. Master's thesis, FEC - Unicamp.

Almeida, R. \& Barbosa, P. S. F. (2002). Efeito da reservação inicial sobre o desempenho operacional de sistemas de abastecimento de água. Anais do Seminário Internacional sobre Projeto e Operação de Sistemas de Abastecimento de Água.

Atamürk, A. \& Savesbergh, M. (2005). Integer-programming software systems.

Carrijo, I. B., Reis, L. F. R., Cheung, P. B., Soares, A. K. \& das Graças Braga da Silva, F. (2003). Otimização da operação de sistemas de distribuição de água utilizando algoritmos genéticos multiobjetivo. Sociedad de Estadística e Investigación Operativa, 11, 152-228.

Guignard, M. (2003). Lagrangean relaxation. Sociedad de Estadística e Investigación Operativa, 11, 152-228.

Nascimento, M. C. V. (2007). Uma heurística GRASP para o problema de dimensionamento de lotes com múltiplas plantas. Master's thesis, ICMC-USP.

Sambasivan, M. \& Schimidt, C. P. (2002). A heuristic procedure for solving multi-plant, multi-item, multi-period capacited lot-sizing problems. Asia Pacific Journal of Operational Research, 19, 87-105.

Sambasivan, M. \& Yahya, S. (2005). A lagrangean-based heuristic for multiplant, multi-item, multi-period capacitated lot-sizing problems with inter-plant transfers. Computers and Operations Research, 32, 537-555.

Seleghim, P. (2003). Otimização operacional do reservatório do douradinho. Relatório Técnico - EESC-USP.

Seleghim, P. (2004a). Otimização operacional da estação do santa felícia. Relatório Técnico - EESC-USP. 
Seleghim, P. (2004b). Estudo operacional da estação do douradinho. Relatório Técnico - EESC-USP.

Toledo, F. M. B., dos Santos, M. O., Arenales, M. N. \& Seleghim, P. (2006). Logística de distribuição de água em redes urbanas - racionalização energética. Artigo submetido na revista Pesquisa Operacional.

Tsutiya, M. T. (2005). Abastecimento de água. Departamento de Engenharia Hidráulica e Sanitária da Escola Politécnica da Universidade de São Paulo, second edition.

Tsutiya, M. T. (2006). Redução do custo de energia elétrica em sistemas de abastecimento de água. ABES - Associação Brasileira de Engenharia Sanitária e Ambiental, first edition.

Wolsey, L. A. (2006). Integer Programming. Wiley Inter Science, first edition. 